\title{
محددات إستفادة الريفيات من إستخدام الهاتف المحمول في المجالات التنموية ببغ قرى محافظة البحيرة
}

\author{
صفاء أحمد فهيم البنداري الديب \\ معهد بحوث الإرشاد الزراعي والتتمية الريفية - مركز البحوث الزراعية
}

الملخص: إستهدف هذا البحث التعرف على محددات إستفادة الريفيات من إستخدام الهاتف المحمول في المجالات التتموية ببعض قرى محفظة البحيرة من خلال تحقيق الأهداف البحثية التالية: التعرف على بعض التصات الخصائص المميزة للمبحوثات، وتحديد درجة إستخدام المبحوثات للهاتف المحمول في الحصول على المعلومات والمعارف المتعلقة بالمجالات التتموية المدروسة، وتحديد درجة إستفادة المبحوثات من إستخدام الهاتف المحمول في

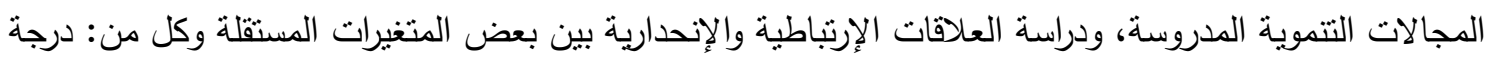

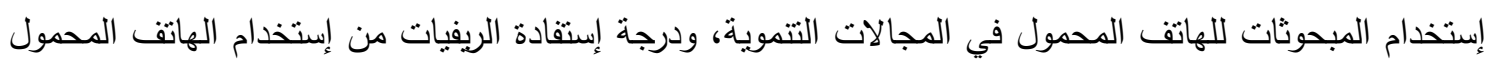
في المجالات التتموية كمتغيرين تابعيين، والتعرف على مقترحات المبحوثات في التغلب على المعوقات التي تحد

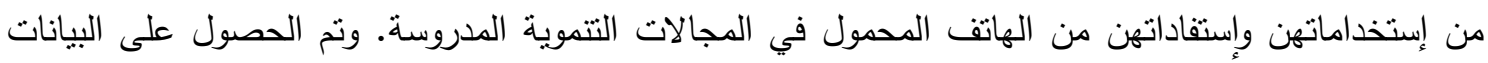

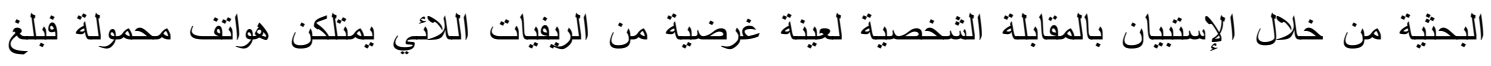

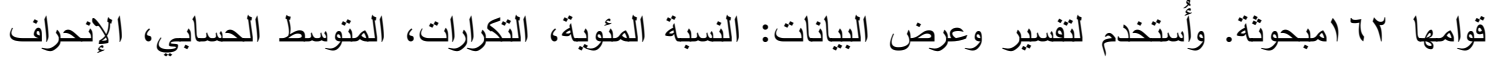

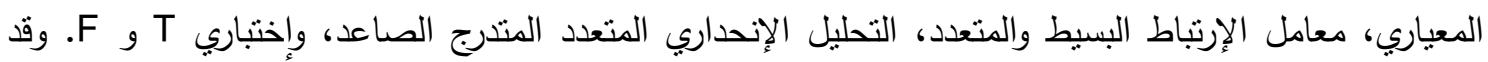

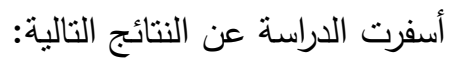
ا- أن المجالات التتموية الآتية: الغذاء والتغذية، والأمومة والطفولة، والصحة، والتعليم، والثقافة، والتسويق، وترشيد

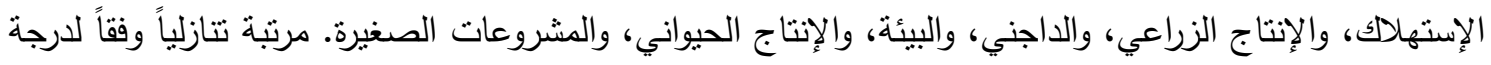
إستفادة المبحوثات من إستخدام الهاتف المحمول. ץ- 1,0 1\% من جملة المبحوثات درجة إستخدامهن للهاتف المحمول في المجالات التتموية منخفضة، في حين

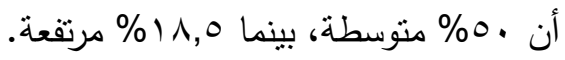

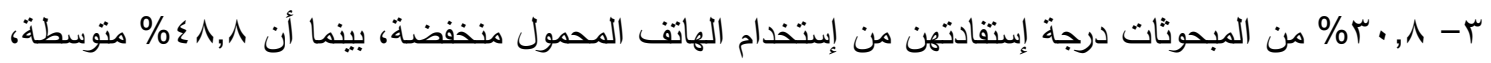

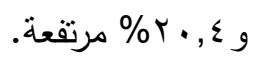

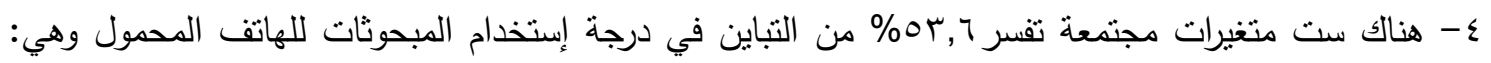
دافعية إستخدام الهاتف المحمول، وحيازة الأسرة من الهواتف المحمولة، ومصاريف كروت الثحن، وعدات دهد المجالات

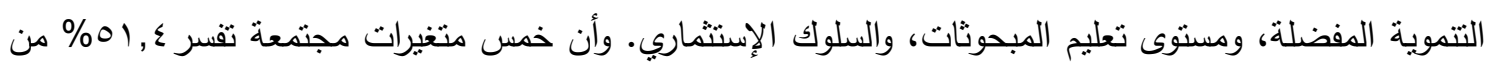
التباين في درجة إستفادة المبحوثات من إستخدام الهاتف المحمول وهي: عدد المجالات التتموية المفضلة، والقيادية، ودافعية إستخدام الهاتف المحمول، والمشاركة الإجتماعية، والمصادر المعرفية الهاتفية.

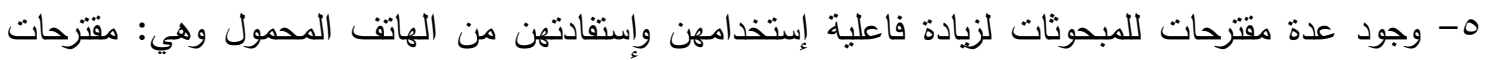
مادية، ومقترحات خاصة بالإنترنت، ومقترحات خاصة بشبكة المحمول، ومقترحات خاصة بالريفيات المبحوثات. الكلمات الدلالية: الإتصال- تكنولوجيا الإتصال والمعلومات - الهاتف المحمول- المجالات التتموية. 


\section{المقدمة والمشكلة البحثية}

تسعى جميع المجتمعات المتقدمة والنامية على حد سواء إلى تحقيق التنمية بمعدلات سريعة مستهدفة بذلك النهوض بالمستويات الإقتصادية والإجتماعية والثقافية لشعوبها، وتكون هذه المجتمعات في سعيها لتحقيق التتمية محدودة بعدد كبير من العوامل التي قد تكون دافعة أو معوقة لعملية التتمية والمتمثلة في الموارد الطبيعية والبشرية

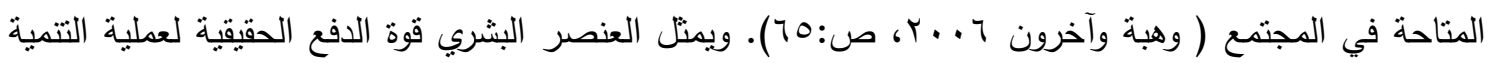
فالإنسان هو غاية التتمية ووسيلتها فلابد من الإهتمام بتتمية الموارد البشرية كدخل للتتمية الحقيقية (خليل وآخرون

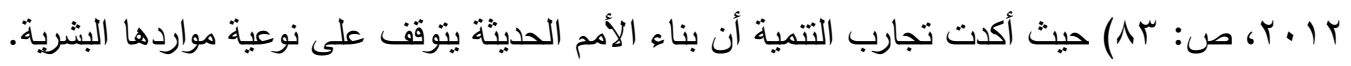
وتعتبر المرأة ركيزة أساسية والثريك المتضامن مع الرجل في عملية التتمية مما يشير إلى حقها في نوعيه

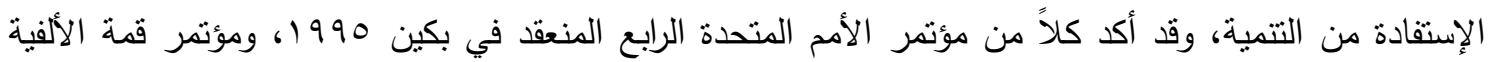

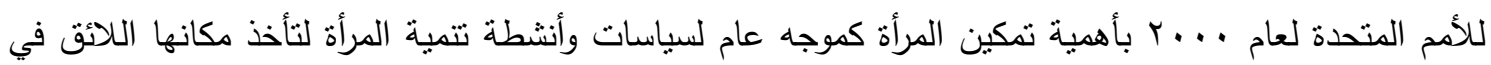
جميع جوانب الحياة مؤكدة على أن حقوق المرأة هي حقوق الإنسان.

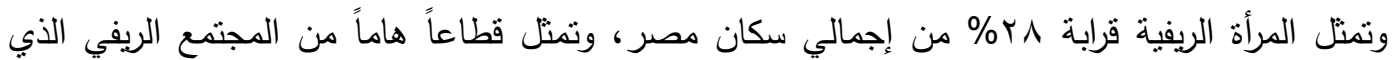

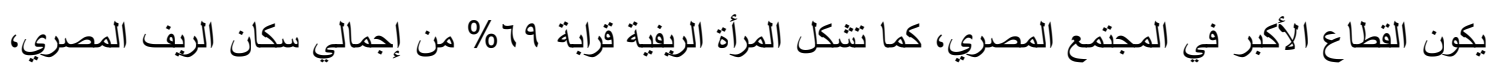

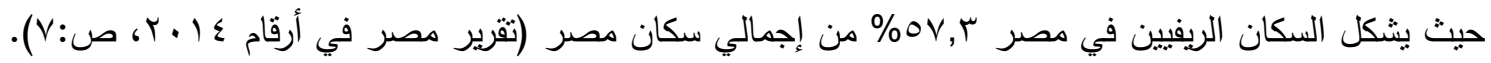
فهي بذلك ثروة قومية هائلة إذا أحسن إستثمارها فمن المكن أن تقوم بدور حيوي ومؤثر في التتمية ليس على

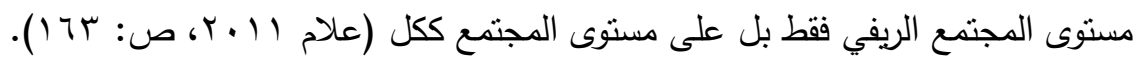
وتتارك المرأة الريفية في التتمية فهي تقوم بدور هام في التتشئة الإجتماعية والمشروعات المولدة للاخل والمشاركة السياسية بالإضافة لأدوار عديدة أخرى في المجالات الإجتماعية والإقتصادية والثقافية والسياسية

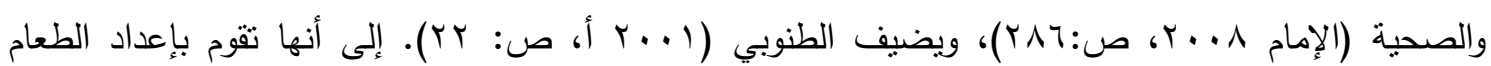

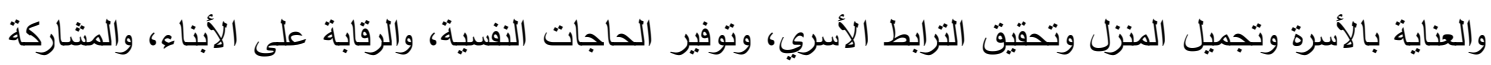
في إتخاذ القرارات، والمحافظة على البيئة، بالإضافة إلى أدوارها الإقتصادية المتمنلة في العمل الزراعي والتخزين المنزلي للمنتجات الزراعية ورعاية الماشية والإنتاج الحيواني ولقد تعددت المناهج والمداخل المقترحة لامج المرأة الريفية في عملية التتمية وفقاً لروئة كل منها فيوجد المدخل التقليدي، والمدخل الديموجرافي الجزئي، ومدخل تقسيم العمل، والمدخل الإقتصادي، ومدخل التحديث، والمدخل التكاملي الثشامل، إلا أن التركيز على المدخل التربوي الذي فرض نفسه في مجال تتمية المرأة الريفية لأنه يتعامل مع نسق الثخصية ويستهدف تتمية معارفها، وتكوين إتجاهات موالية للتنمية، مع العمل على تطوير مهاراتها الخاصة وذلك من خلال تعرض المرأة الريفية لبعض الممارسات الجديدة المستحدثة مع توفير التدريب

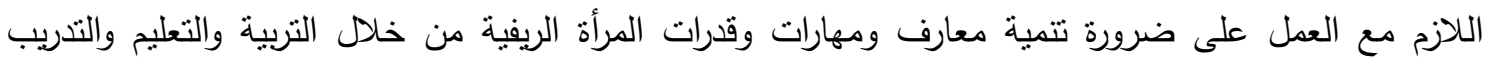

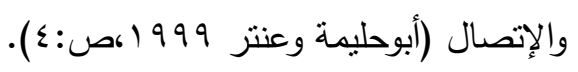

ومع كثرة الأعباء والمهام التي تقوم بها المرأة الريفية فإنه يتعين تقدير هذا الدور عند إختيار طرق الإتصال المستخدمة في نقل المعارف والرسائل المعلوماتية اليها وفي إكتسابها المهارات اللازمة والعمل على تتمية قدراتها

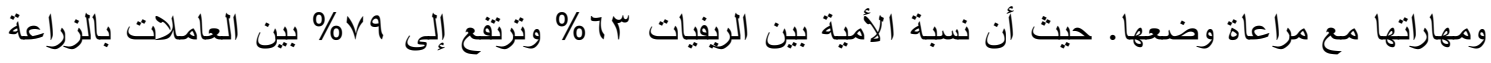

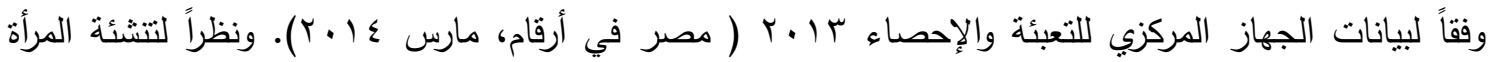
الريفية الإجتماعية التي تؤدي لتضييق حركتها خارج حدود وطنها المحلي -منزلها خاصة- مما يؤدي لصعوبة مارية 
الإنتقال خارج هذا النطاق، وفي ضوء الدراسات التي إجريت في مجال الطرق الإرشادية والإتصالية ودرجة تفضيلها لها تبين أن طرق الإتصال المباشر وشبه المباشر هي أفضل الطرق الإتصالية في التعامل والإتصال مع المرأة

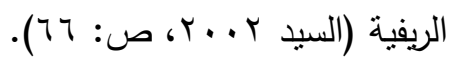

وتعتبر الإتصالات الهاتقية من طرق الإتصال الفردي التي لها مكانة هامة في توفير الثقة وتتمية العلاقات

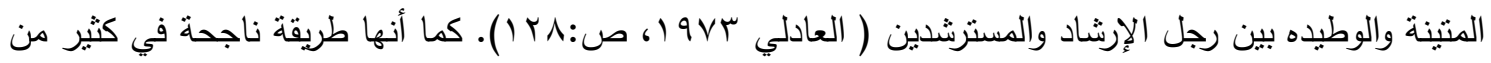

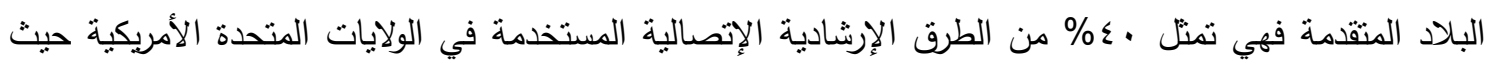

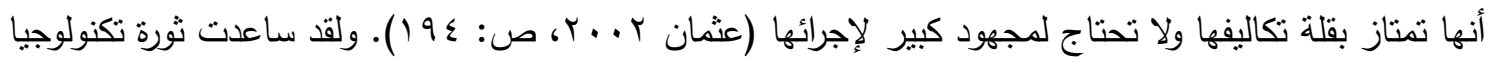

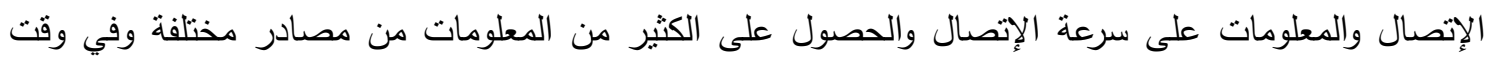

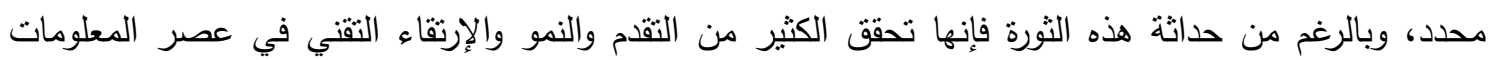

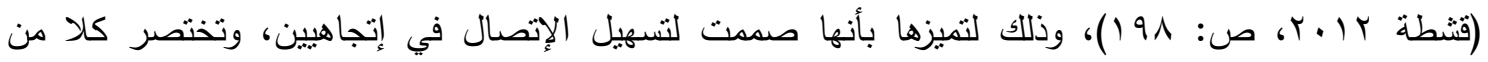

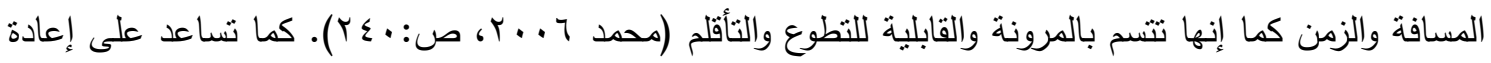
تتكيل كثير من طرق الحياة الإعتيادية للأفراد والمنظمات وحتى الدول من إتصال وبحث وبيع وشراء وتوزيع وحتى إنى

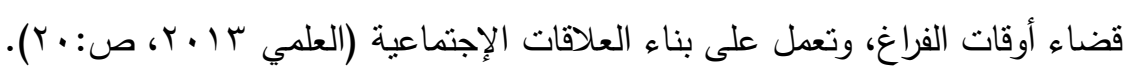
وفي هذا الإطار نباشر الهواتف المحمولة عملها كطريقة إتصالية ناتجة من ثورة تكنولوجيا الإتصال، حيث أصبح يسيطر موضوع إستخدام الهواتف المحمولة حالياً على المناقتشات بين العامليين في مجال الزراعة الإككترونية من أجل التتمية (ICI4D) وينظر إليها بإعتبارها حافز للإندماج الإجتماعي، فهي تقدم مجموعة كبيرة

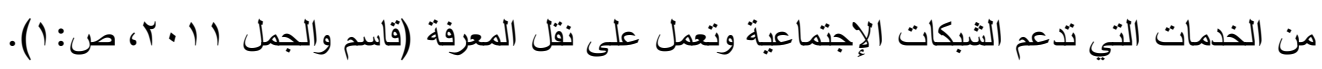
وقد تجاوزت وظائف الهاتف المحمول عملية تبادل المحادثات بنفس قدرتها على تجاوز المكان، وساعد الإمتزاج بين تكنولوجيا الحاسب الآلي والهاتف الدحمول على التوسع في هذه الوظائف والتي منها: الراديو،

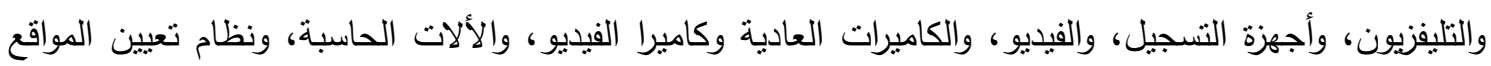
GPS المكتوبة والصوتية المسجلة وغيرها (قاسم 9 . . ب). وإن الهواتف المحمولة التي كانت من قبل من الأشباء النادرة

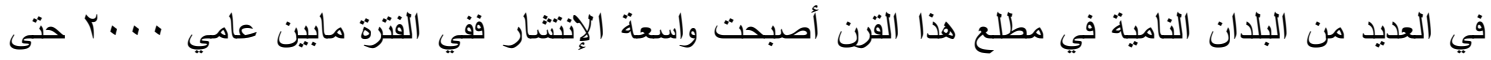

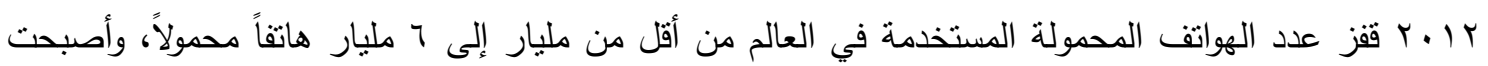

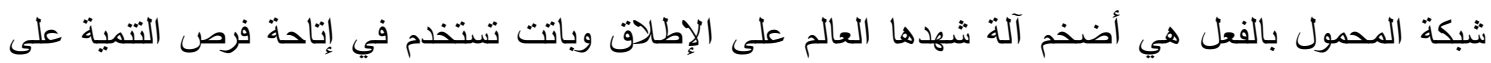

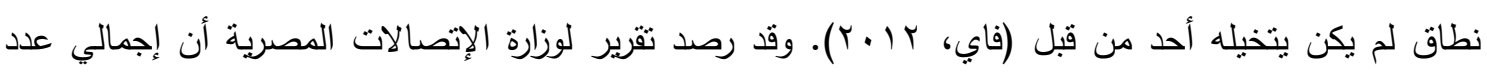

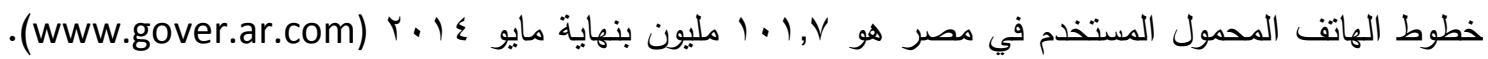

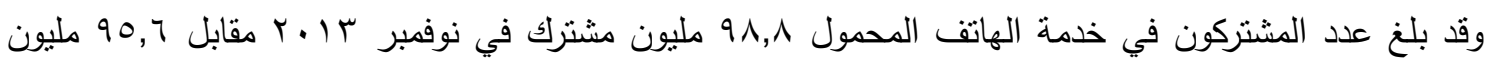

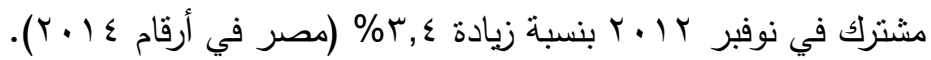

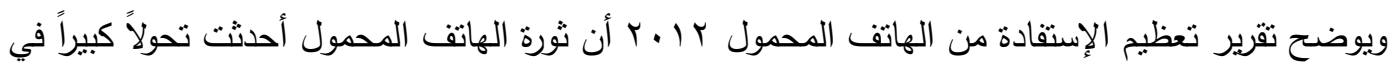
التتمية، فإن إستخدامها يتيح فرصة كبيرة لدفع التتمية البشرية قدماً في البلدان النامية، حيث تعمل على توفير سبل للحصول على المعلومات في مجال الخدمات الصحية، وفي الزراعة، وفي الخدمات الحكومية، وفي المعاملات

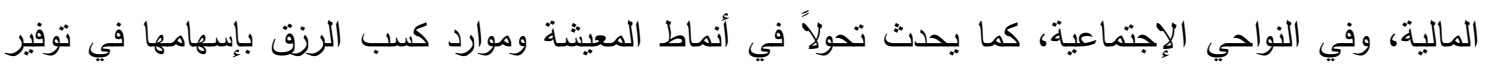


أنشطة أعمال جديدة كما في الأعمال المتتاهية الصغر، ومشاريع العمل الحر، والتوظيف، كما يعمل على تحفيز

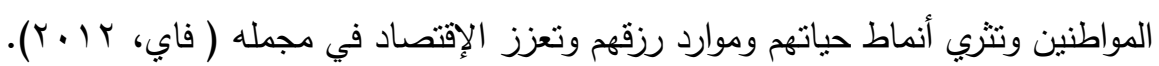
ويمكن الإستفادة من خصائص الهواتق المحمولة لدعم عمليات النتمية حيث أنها: قناة الإتصال موثثوق فيها، وحاضرة للتواصل في مجالات عديدة منها: الإششاد والصحة والأسواق والتعليم، وتقدم أثنكال صياغة متعددة

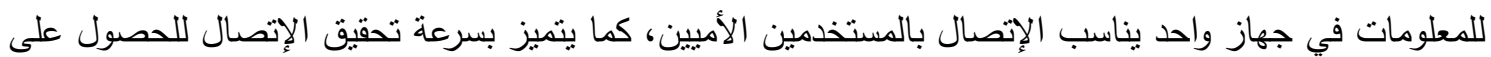

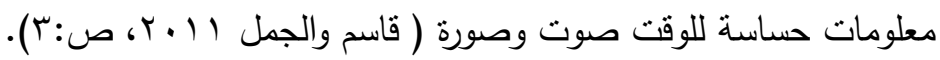

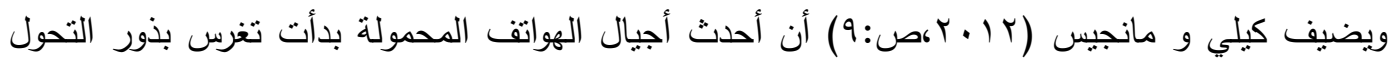
الإجتماعي والسياسي فضلاً عن الإقتصادي، وأما في مجال الزراعة فقد أصبح بمقدور المزارعين في أفريقيا (تنزانيا- نيجيريا- مالاوي) الحصول على المعلومات المتعلقة بالأسعار من خلال الرسائل النصية، وقد براعه فئن

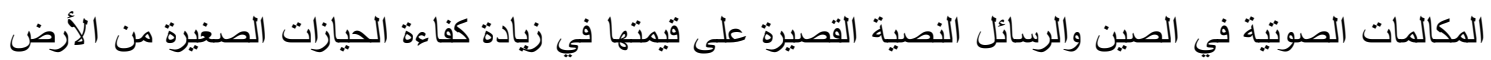

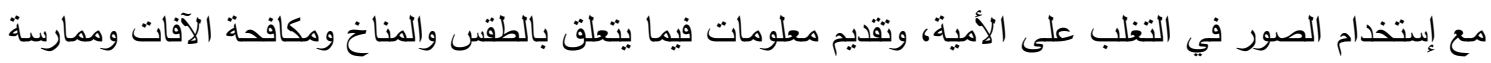

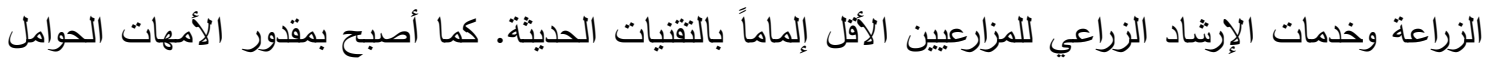
الحصول على تقرير طبية بشأن تقدم حملهن عبر الهاتف، كما صار بإستطاعة العمال المغتربين بإرسال تحويلاتهم النقدية دون المرور عبر البنوك.، كما اتاحت الهواتف المحمولة فرصاً غير مسبوقة أمام التوظيف بأفئ والتعليم والترفيه في البلدان النامية.

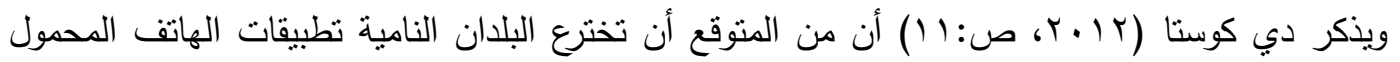
الخاصة بها أو أن تطوع ما هو موجود منها لكي تتتاسب مع الظروف والإحتياجات المحلية، ولذلك فإن هناك لطات حاجة لإجراء مزيد من البحوث بشأن كيفية إستخدام الأسر الفقيرة التي تقع عند قاعدة الهرم الإقتصادي لنطبيقات الهاتف المحمول. كما يمكن إستخدام الهاتف الهحمول في التعليم حيث تقدم "مبادئ اليونيسكو التوجيهيه بشأن

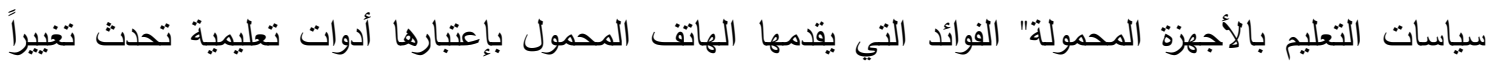
إيجابياً في مجال التعليم، حيث تتيح سهولة إستعمالها وأسعارها المعقولة زيادة الفرص التعليمية للارسين في سباقات مختلفة بما في ذلك المناطق التي لا يتوافر فيها سوى القليل من الموارد التعليمية التقليدية. ومنل كل التقنيات يحد من إستخدامها بعض القيود والتحديات في المناطق الريفية منها: إرتفاع تكاليف لهن شراؤها وخاصة هواتف الجيل الجديد، ومحدودية تغطية الثبكة، وإنخفاض عرض النظام الفردي في بعض المناطق الريفية، القدرة المحدودة لسكان الريف على إستخدام التكنولوجيا، وقلة الوعي بالفوائد المتوقعة من إستخدامات

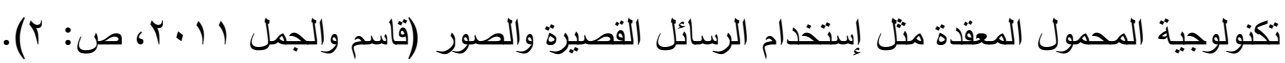
ونظرأ للدور الحيوي الذي تقوم به المراة الريفية في التتمية كان من الضروري دراسة وسيلة إتصال حديثة تعمل على تغذية الريفيات بالمعلومات والمعارف التتموية التي نساعدها على اداء أدوارها بكفاءة وفاعلية والوصول فئه

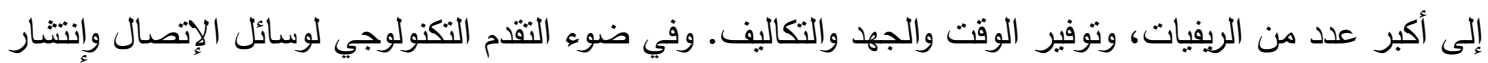
الهاتف المحمول في جميع المناطق عامة والريفية خاصة كوسيلة إتصال سريعة وبتكلفة محدودة، ونظراً لأهمية السرعة في نقل المعلومات للريفيات وهو ما قد يكون له دور وأثز كبير في إحداث تغييرات معرفية ومهارية مرغوبة لتتمية المرأة الريفية والمجتمع الريفي، مع العمل على سرعة التواصل بين الريفيات وبعضهن وبين أفراد مجتمعهن.

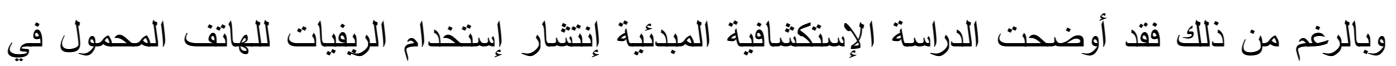
عدة مجالات شتى مثل: المجال الزراعي بشقيه النباتي والحيواني، والتعليمي والصحي والتغذوي والبيئي...الخ. 
وغيره وذلك راجع إلى إهتماماتهن الأسرية والمنزلية والمجتمية فهن يسعين لما يشبع حاجاتهن ويسد العجز في

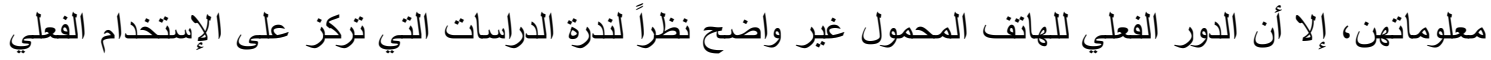

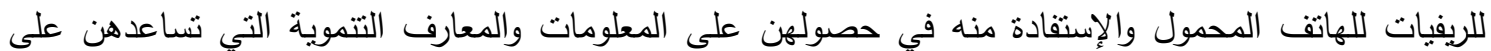
تحسين مستوياتهن المعيشية والإجتماعية. ولذلك فإنه يتبادر إلى الذهن عدة نساؤلات تتبلور بعضها حول: ماهو نطاق عمل الهاتف المحمول كمصدر لمعلومات ومعارف الريفيات الأمر الذي يفتح المجال لإمكانية الإستعانة به في توصيل المعلومات والمعارف والإستفادة منه ومن ثم تزداد قاعدة المستفيدات منه، ويتعاظم دوره في تحقيق الإتصال الإرشادي، ولذلك أجريت هذه الدراسة كمحاولة للإجابة على هذه التساؤلات مع التعرف على المجالات التتموية التي تسنطيع الريفيات

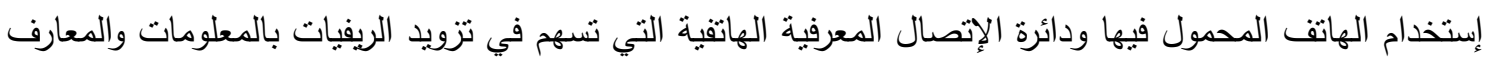
التي تمكنهن من النهوض بمستوياتهن المعرفية والمهارية في المجالات التتموية المختلفة.

\section{الأهداف البحثية}

إستهدف هذا البحث بصفة عامة ورئيسية التعرف على محددات إستفادة الريفيات من إستخدام الهاتق المحمول في المجالات التتموية ببعض قرى محافظة البحيرة من خلال تحقيق الأهداف الفرعية التالية: 1- التعرف على بعض الخصائص المميزة للمبحوثات الريفيات.

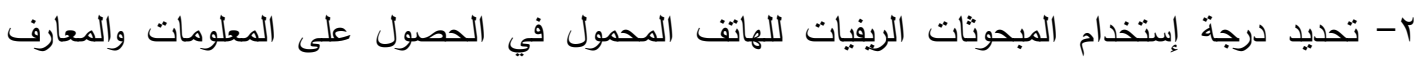
المتعلقة بالدجالات التتموية المدروسة. ז- تحديد درجة إستفادة المبحوثات الريفيات من إستخدام الهاتف الدحمول في المجالات التتموية المدروسة. ع - دراسة العلاقات الإرتباطية والتأثيرية بين بعض المتغيرات المسنقلة وكل من درجة إستخدام المبحوثات للهاتف المحمول،ودرجة إستفادة الريفيات من إستخدام الهاتف المحمول في المجالات التتموية المدروسة. ه- التعرف على مقترحات المبحوثات الريفيات في التغلب على المعوقات التي تحد من إستخدامهن وإستفادتهن من الهاتف المحمول في المجالات التتموية المدروسة.

\section{الأهمية البحثية}

تعتبر هذه الدراسة من أوائل الدراسات الإرشادية المتخصصة في مجال إستخدام تكنولوجيا الإتصال التي تتاولت بالوصف والتحليل إستخدام الريفيات للهاتف المحمول والإستفادة منه، ودوره في نتمية المرأة الريفية خاصة التي لها دور هام في تتمية القطاع الريفي. كما نتبثق اهمية هذه الدراسة فيما يمكن أن تسفر عنه من نتائج علمية مستمدة من الواقع تزيد من فرص معرفة الريفيات بإستخدامات الهاتف المحمول، والإستفادة منه كوسيلة إتصالية حديثة في المجالات التتموية وكذلك نوفر المقترحات للتغلب على المعوقات التي تحد من إستخدام وإستفادة الريفيات من الهاتف المحمول على نطاق واسع في المجالات التتموية، فضلاً على إرتباط مجال هذه الدراسة بعملية نقل وتوصيل المعلومات والمعارف والتقنيات الحديثة للريفيات والتي تمثل جوهر العملية التعليمية الإتصالية الإشنادية.

\section{الفروض البحثية}

تحقيقاً للهدف البحثي الرابع لهذه الدراسة نم إختبار الفرضين البحثين التاليين:

ا- توجد علاقة معنوية بين كل من: سن المبحوثات، والمستوى التعليمي للمبحوثات، والمستوى التعليمي للزوج، وحجم الأسرة، والمشاركة الإجتماعية، والتعرض لوسائل الإتصال الجماهيرية، وعدد مصادر المعلومات، والتجددية، 
والقيادية، والسلوك الإستثماري، وحيازة الأسرة من الهواتف المحمولة، وعدد كروت الثحن الثهرية، ومصاريف كروت الثحن الثهرية، ودافعية إستخدام الهاتف المحمول، ودرجة مناسبة الهاتف المحمول، والمجالات التتموية المفضلة، والمصادر المعرفية الهاتفية للمبحوثات، ومصادر الإتصال المعرفية بالمبحوثات كمتغيرات مستقلة، ودرجة إستخدام الريفيات للهاتف المحمول في بعض المجالات التتموية المدروسة. ويتم إختبار هذا الفرض في صورته الصفرية. ץ- توجد علاقة معنوية بين كل من: سن المبحوثات، والمستوى التعليمي للمبحوثات، والمستوى التعليمي للزوج، ولهن وحجم الأسرة، والمشاركة الإجتماعية، والتعرض لوسائل الإتصال الجماهيرية، وعدد مصادر المعلومات، والتجدية، ولئ،

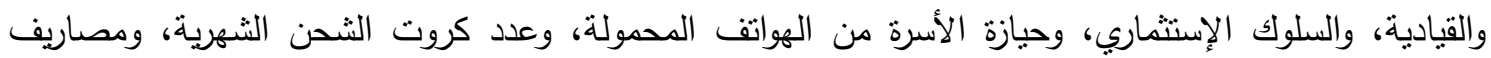
كروت الثحن الثهرية، ودافعية إستخدام الهاتف المحمول، ودرجة مناسبة الهاتف المحمول، والمجالات التتموية المفضلة، والمصادر المعرفية الهاتقية للمبحوثات، ومصادر الإتصال المعرفية بالمبحوثات كمتغيرات مستقلة، ودرجة

إستفادة الريفيات للهاتق المحمول في بعض المجالات التتموية المدروسة. ويتم إختبار هذا الفرض في صورته الصفرية.

الإطار النظري

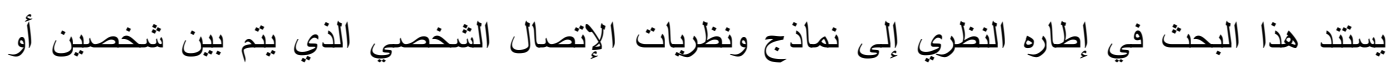

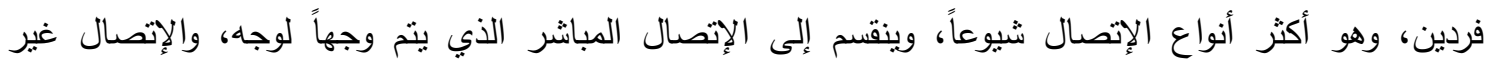

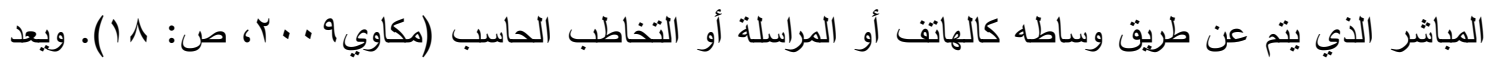
هذا الإتصال من أفضل مستويات الإتصال حيث يوفر للمرسل فرصة التعرف المباشر على درجة تاثثر رسالثه

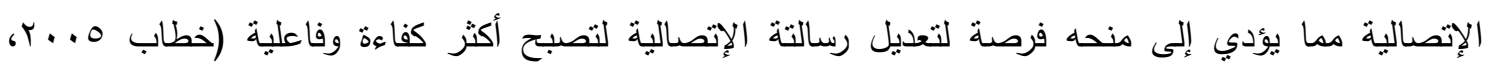
ص:^^ا). ولقد تعددت نماذج ونظريات الإتصال الثخصي ولكل منها زاوية نطل على عملية الإتصال ومنها:

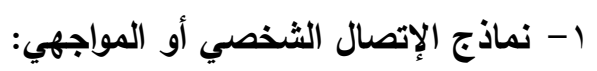
أ- نموذج (ديفيد برلو): وهو من النماذج التي يجب على المصدال المدر والمستقبل أن يحدد كل منهما أهدافهما من

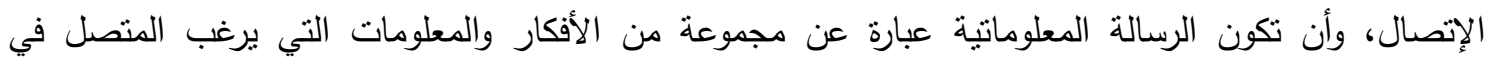

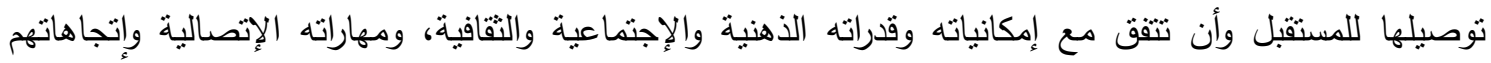

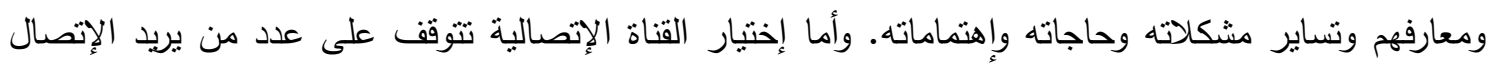

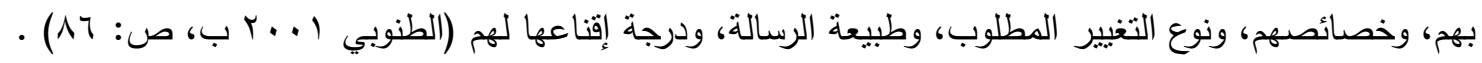
ب- نموذج (روجرز وكنليد): وهو يركز على أهمية المعلومات والطريقة التي تربط الأفراد، ومن خلال الإتصال

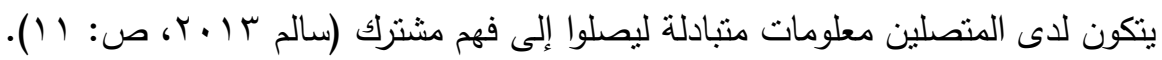
ويمكن الإستفادة من هذه النماذج في تحديد مضامين الرسائل الإتصالية والهذف منها، وتتحصر في بعض

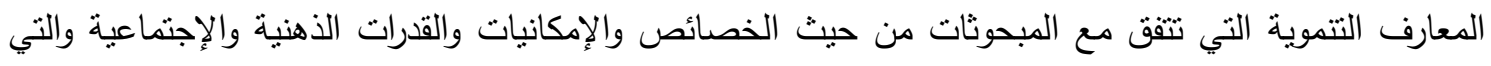

يتم الحصول عليها من خلال إستخدام قناة الإتصال المنمنلة في الهاتف المحمول والعمل على الإستفادة منها. r-نظريات الإتصال الشخصي:

أ- ومنها نظرية الإرجاع أو الغزو: Attribution Theory وتحاول هذه النظرية توضيح أسباب سلوك بعض الأفراد سلوكاً معيناً والوصول إلى تفسير معقول لهذا السلوك. وهذا يرجع لأسباب داخلية وهي تتبع من الفرد تجاه الحدث أو الثخص، وأسباب خارجية تتعلق بالبيئة 
المحيطة بالحدث أو الثخص، وتقودنا هذه النظرية إلى دوافع الأفراد ومشاعرهم وعواطفهم ومعتقداتهم المؤثرة على توجهرم نحو الأحداث، ويتم تحديد هذه الأسباب عن طريق سؤال الأفراد عن أسباب توجهه نحو كل شئ (سالم

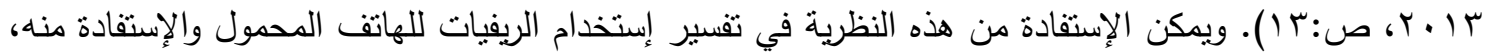

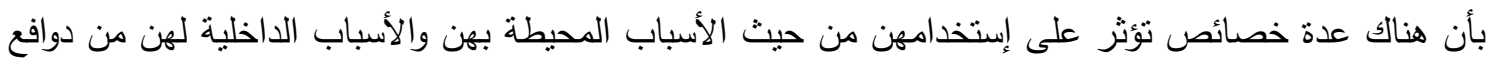
ومشاعر ومعتقدات وإتجاهات تؤثز في تفضيل إستخدام الهاتف المحمول والإستفادة منه.

ب- نظرية التنافر المعرفي: Cognitive Dissonance وهي نظرية عامة للسلوك البشري وتغطي مجال الإتصال البشري كله وتهتم بالتغيرات السيكلوجية الداخلية وعلاقة الفرد الإتصالية بالآخرين. فعادة ما يتقق سلوك الفرد مع معارفه، ولكن في بعض الحالات يحدث نعارض أو تتافر بين تصرفات وسلوك الفرد ومعارفه ففي هذه الحالة سوف تبدأ عمليات سيكلوجيه تحفزه للوصول لمرحلة

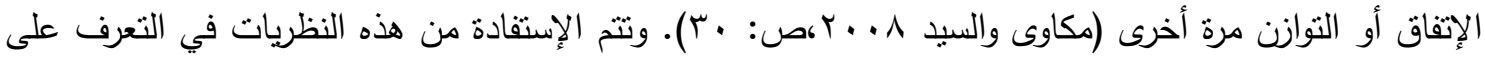

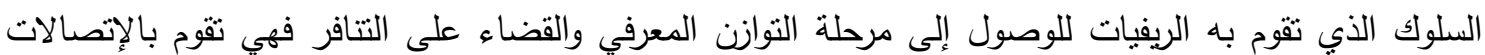
الهاتقية بإستخدام الهاتف المحمول لسد العجز في معارفها ومعلوماتها وللإستفادة منها وإحداث التغييرات السلوكية

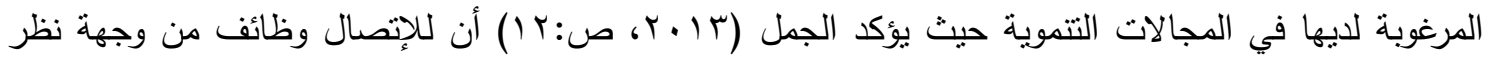
المتلقين تتمثل في الحاجة إلى المعلومات، والتسليه والترفيه، والأخبار عن مشكلات الساعة، والحاجة إلى رفع لهع مستوى المعارف والثقافة العامة، والحاجة إلى دعم الإتجاهات وتعزيز المعايير والقيم والإتجاهات الإيجابية.

الإستعراض المرجعي

تعد طرق الإتصال بالأفراد في مقدمة الطرق الإرشادية الإتصالية بل هي أساس الإرشاد الصحيح والفعال

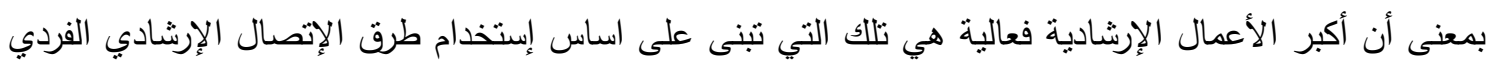

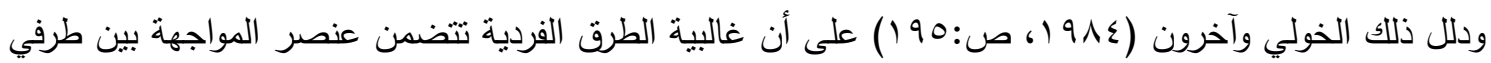
العملية الإرشادية، واستخدام هذه الطرق يعني ضمناً إقامة موقف إتصالي إرشادي أمتل. وتعتبر الإتصاللات

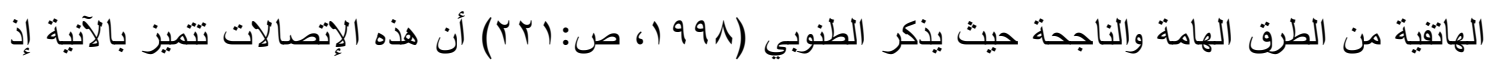

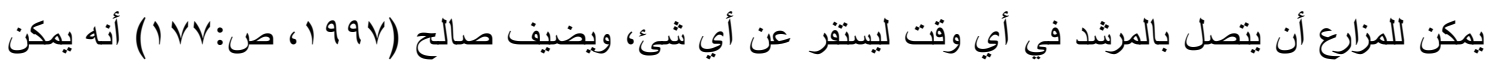
الإستعانة بالتليفون في الظروف التي لا يتمكن فيها طرفا الإتصال من إجراء الزيارات واللقاءات الشخصية المباشرة. وتذكر (Saravanan 2011) أن الهاتف المحمول ( الموبايل) يعتبر أحدث الثورات في العملية الإتصالية وأصبح الكل في واحد حيث ينت من خلاله التخزين وتبادل المعلومات في أي وقت وفي أب مكان بغض النظر عن

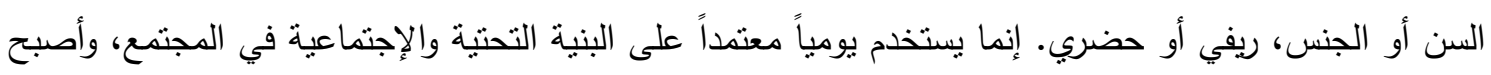

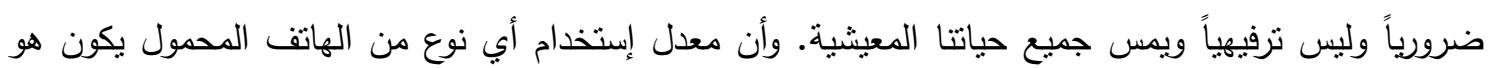
الدليل للمرشد والمزارع والباحث والمتخصص الإرشادي وصانع القرارات الزراعية على نجاح إستخدامه في مجال

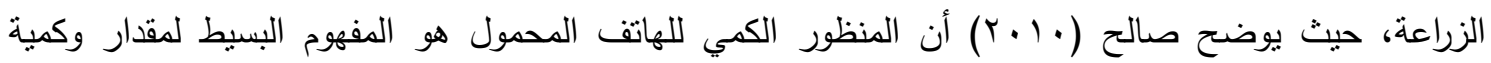
إستخدام الهاتف المحمول وينتج عنه تصور متعدد الأبعاد يكثف عن كيفية الإستعمال من حيث:عدد مرات

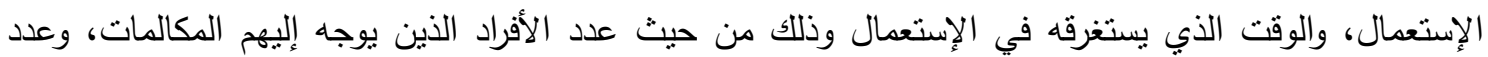

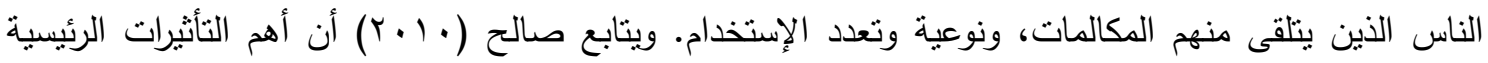

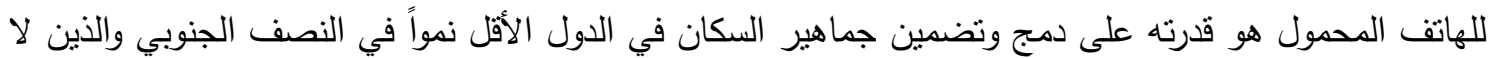
يمتلكون قدرات على حيازة الخط الأرضي التليفوني. 538

Vol. 20(3), 2015 
الاراسات السابقة

في بنجلادش قامت الفاو (FAO,1998) بدراسة عن"مشروع الهاتف المدفوع فى القرى" فقد اقام نظاماً

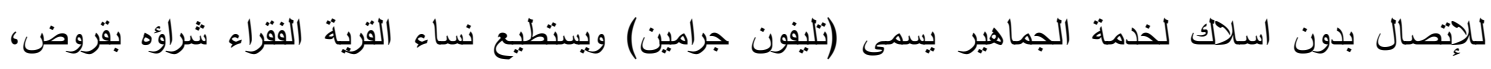
ويستطيع سكان القرية إستعماله مقابل أجر بسيط. وبهذه الطريقة يساعد البنك نساءالريف على إدارة أعمالهن التجارية ويمكنهن من الإتصال بالموردين والعملاء والحصول على المعلومات الخاصة بالأسواق بشكل سريع

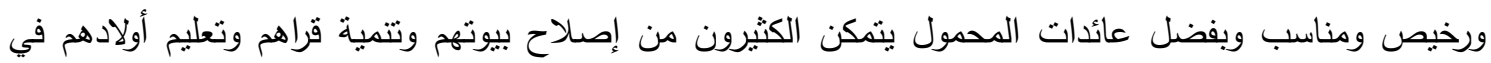
المدن والحصول على خدمات صحية، كما تؤمن خدمة الهاتف الدحمول من عمليات إرسال تحويلات مالية من ون عمال بالخارج إلى أهاليهم في بنجلادش خوفاً من الإسنيلاء عليها مستغلين أمبة أصحابها. وفي دراسة عن تعدد إستخدامات الهاتف المحمول وجد (Oungs,2002) حدوث تغييرات نموذجية في إستخدام الهاتف المحمول حيث أنها غزت وسيطرت على مختلف الأعمار، وكافة الأوقات، وتغلبت على مشكلة الأمية. كما انه يؤدي وظيفة إجتماعية: التضامن، والإلتزام، والإشفاق، والتعاطف.

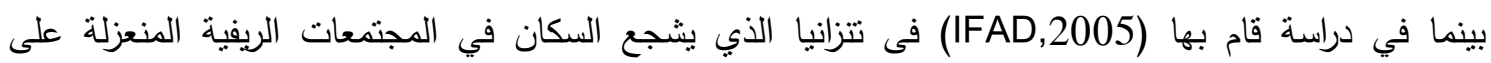
إستخدام الهواتف النقالة لتحسين فرص وصولهم الى الأسواق، وحصولهم على معلومات أكثر دقة عن حالة الثان الأسعار على إمتداد سلسلة الأسواق فهي نسه في شفافية الأسواق. وتمنعهم من الإستغلال في بيع محاصئ واصيلهر

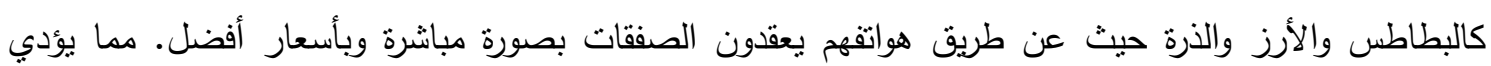
لزيادة أرباح المزارعيين من خلال معلومات السوق، ويعطي قدراً من الثقة بالنفس، ويؤدي إلى ثورة في التسوق،

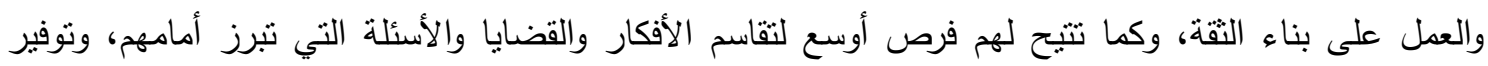
القدرات الإبتكارية للمزارعيين من خلال (مجموعات تقديم الخدمات) حيث يمكن تبادل المعلومات مع نظراء يعيشون بعيداً عنهم فيؤدي لحلول مبتكرة للتحديات والمشاكل. وفي دراسة عن الصيادين بالصين (17-pp5) تبين أن إنتشار التليفون المحمول بين الصيادين أدى إلى رفع الكفاءة التسويقية من خلال تتسيق العرض والطلب، والتدفق السريع للمعلومات التي تلبي الطلب في الأسواق، والقدرة على الرد السريع بين الموردين والأسواق. وقد أنشأت الحكومة الصينية شبكة التليفون

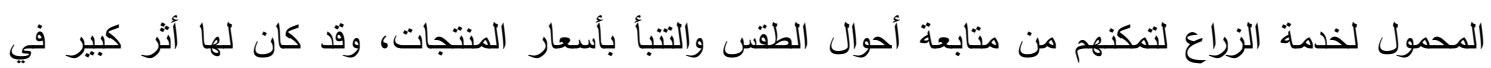
مساعدة الزراع على الحصول على معلومات مفيدة نساعدهم في التخطيط الإنتاجي الفعال، كما يساعدهم في تربية

الماثنية وزيادة معارفهم عن السوق والإتصال بالغرباء للعمل والإنفتاح والتسوق (Fong,2009:pp1-12).

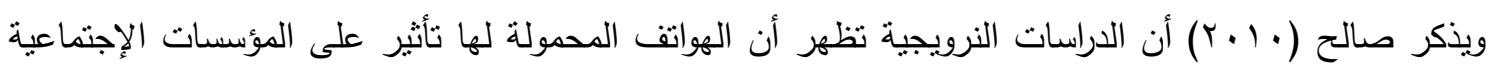

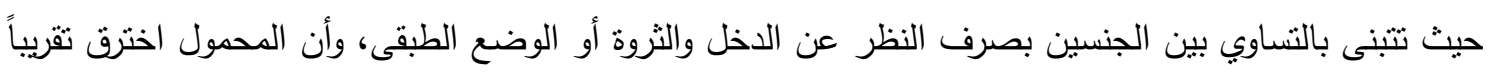
كل فئات العمر بصرف النظر عن التعلم أو الجذور الإجتماعية، فهو يعمل على سد الفجوات بين الطبقات الإجتماعية المختلفة في المجتم. وتوضح أرقام هيئة الإتصالات الصينية أن عدد الرسائل القصيرة المنتشرة ظاهرة تقافية جديدة في الصين غير مسبوقة ويسموها (تقافة الأصابع) التي نستعمل في الإتصال الجديد. وفي دراسة نم إجرائها في تنزانيا عن مساهمة التليفون المحمول في الحد من الفقر توصلت إلى أن التلافيون المحمول ساهم في الحد من الفقر وتحسين مستوى معيثة المناطق الريفية من خلال توسيع شبكة العلاقات

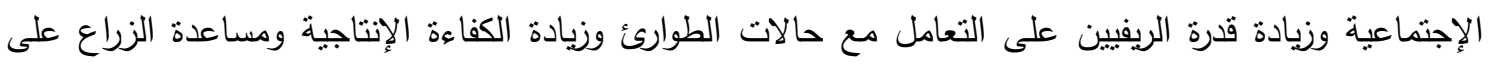

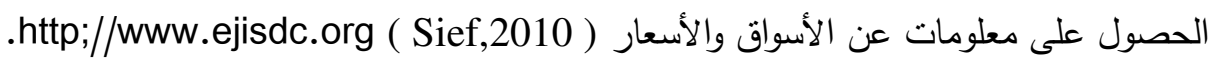


وفي دراسة قاما قاسم والجمل (1) (1) بدراسة إستخدام الزراع للهاتق المحمول في الإتصالات المتعلقة بالزراعة وقد استهدفت التعرف على الخصائص الفنية للهواتف المحمولة التي يستخدها الزراع المبحوثين، والتعرف على إستخدام الزراع للهاتف المحمول في الإتصالات بأفراد وجهات لأغراض تتعلق بالزراعة، والتعرف على لهى الجهات والأفراد والتي تتصل بالزراع على هواتفهم المحمولة لأغراض تتعلق بالزراعة، والتعرف على الخدمات الإرشادية التي يرغب الزراع في الحصول عليها عن طريق الهاتف المحمول وتفضيلهم لطريقة الحصول عليها. وتم إجراء الدراسة في سبعة مركز إرشادية تم إختيارها من ست محافظات موزعة على مستوى الجمهورية تم إختبارهم

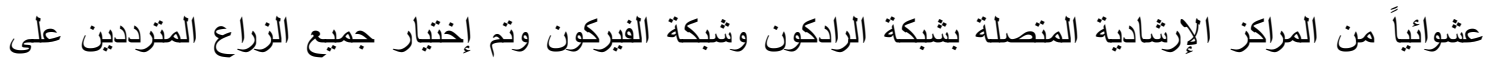

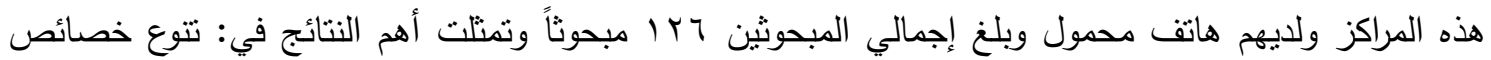

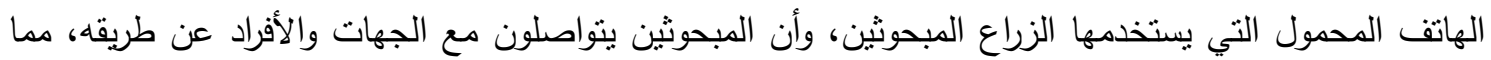
يبرز أهيته فى تيسير الإتصال للزراع، واحتلت حل المشكلات الزراعية، ومعرفة أسعار المدخلات الزراعية المراتب المتقدمة في الأسباب التي يتصل بسببها الزراع. أما عن كثافة الإتصال بمصادر المعلومات بإستخدام الهاتف المحمول فيمكن إعتبار الجمعية الزراعية والمرشد الزراعي هي أكثر هذه المصادر نقة لدى الزراع.

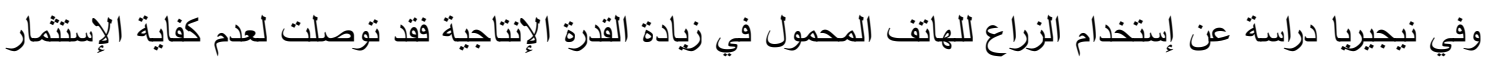

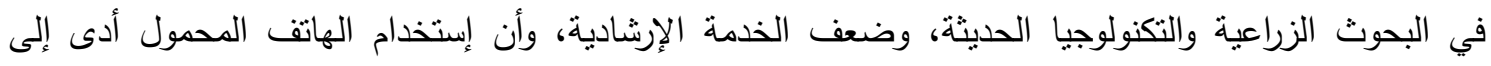

تحسين كفاءة المدخلات الزراعية وتحسين إنتاجية المحاصيل الزراعية (Bolariuma and Oyejinka,2011).

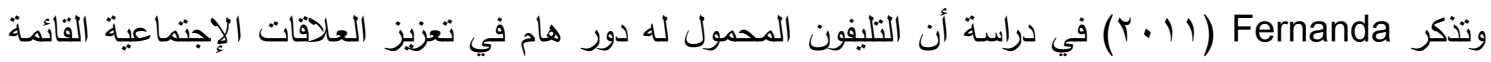
بالفعل، والتواصل بين الأقارب والأصدقاء وما لها من ناثير على النشاط الإقتصادي منل التحقق من الأسعار وجمع معلومات عن الأسواق.

وفي دراسة في موريثيوس عن نأثثر التليفون المحمول على التتمية الزراعية أكد المزارعين أن أكبر ميزة

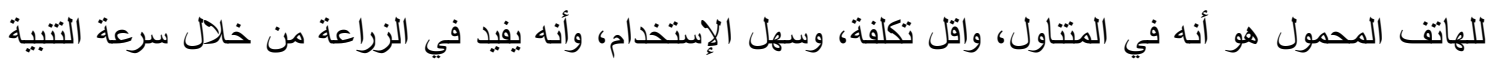

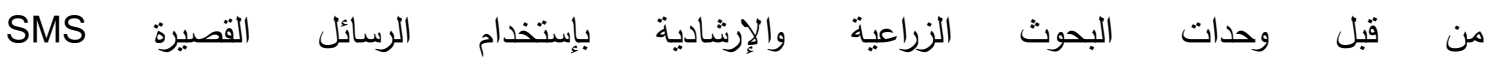
ونت عمل دراسات من قبل جامعة كانساس في الهند والصين لدراسة تتجيع إستخدام الهاتف المحمول في القطاع الزراعي لإثبات انه فعال في مجال المعلومات والبرامج الزراعية (https://kuscholarworks.ku.edu.2011)

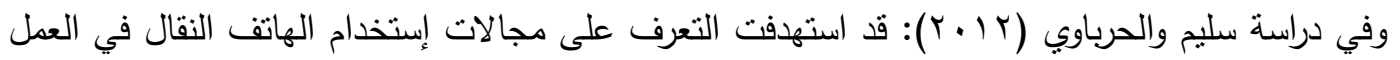

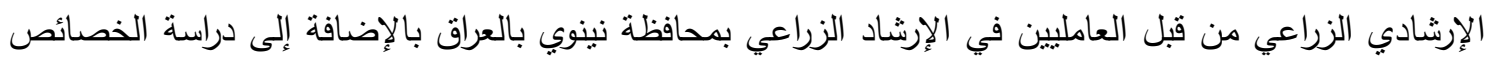

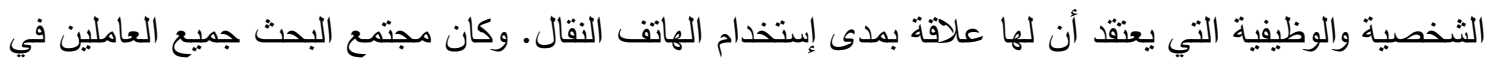

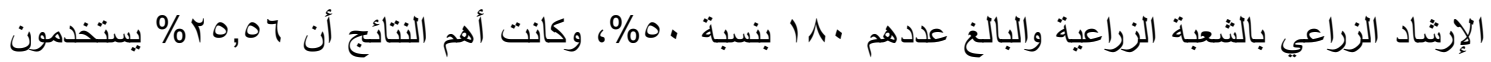

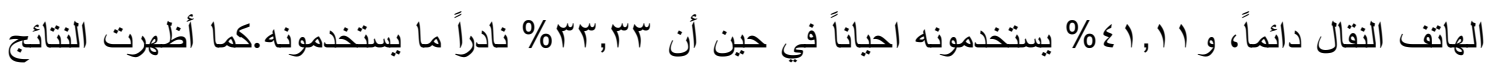
وجود علاقة إرتباطية معنوية بين مدى الإستخدام وموقع العمل فقط، وعدم وجود علاقة مع المتغيرات: طبيعة العمل، والوظيفة، والتخصص الدراسي. ووجود مجموعة من المعوقات تحد من إستخدام المبحوثين للهاتف النقال على الرغم من إدراكهم لأهميتة في العمل الإرشادي.

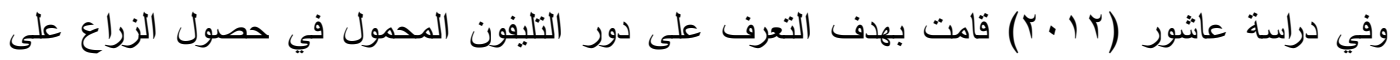
المعرفة الإرشادية في المجالات الزراعية المختلفة من المصادر المعرفية المختلفة والإستفادة منه وبلغت عينة 


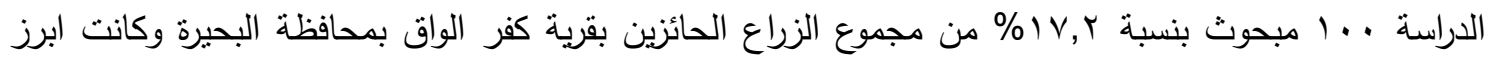

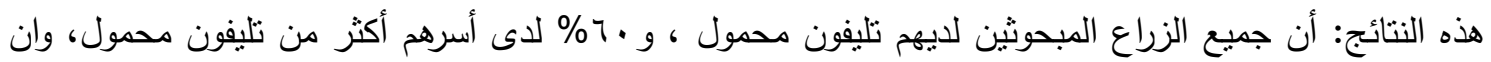
أهم معوقات إستخدام التليفون المحمول في المجال الزراعي هي مصاريف المكالمة، وأن مجال بيع المحاصيل الزراعية، ومجال الأمراض التي تصيب الخضر هما أكثر مجالات الإنتاج النباتي التي يرى المبحوثين مناسبة

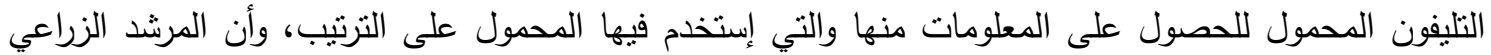
أكبر مصدر للمعلومات التي استفاد منها المبحوثين في مجالي الإنتاج النباتي والحيواني. وفي دراسة لإستخدام Smart Phone

وإستخدامة في القطاع الزراعي وجد أن له أنز فعال لقطاع عريض من الأشخاص في مجال التتمية الريفية. وفي دراسة عن إستخدام GSMA (2014) الخدمات الإرشادية الزراعية للنساء من خلال الهواتف الهحمولة للريفيات وجد أنه يعمل على حل المشكلات الريفية والمنزلية والزراعية في الهند

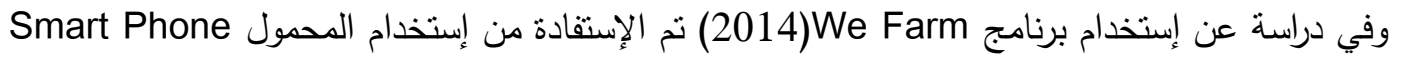

في تبادل المعلومات وحل المشكلات بين الزراع على مستوى العالم من خلال الإنترنت بالتليفون المحمول.

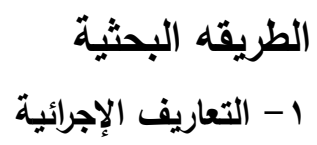

أ- المجالات التتموية: يقصد بها مجالات التتمية الريفية والزراعية التي من شأنها التعامل مع المرأة الريفية وتتميتها

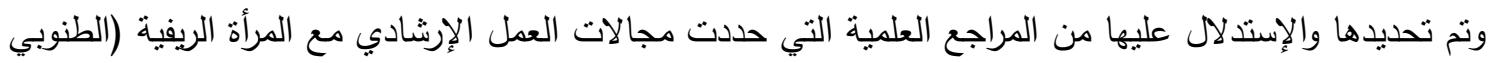

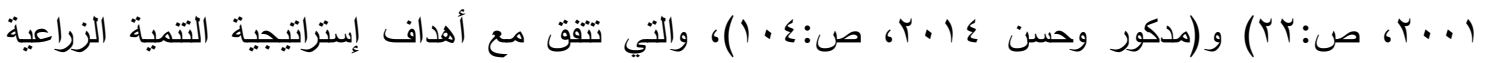
المصرية حتى عام ·r.r.r، وقد تمنلت في المجالات المعنية بكل من: الإنتاج الزراعي، والإنتاج الحيواني، والإنتاج

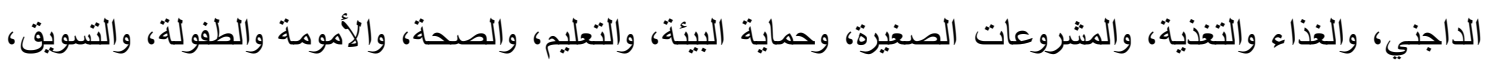

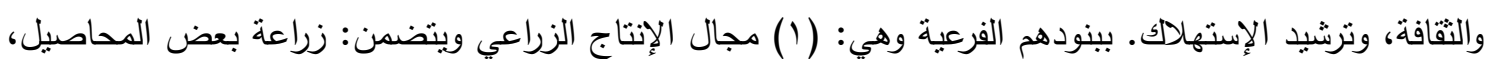
وتسويق بعض المحاصيل.(r) مجال الإنتاج الحيواني: ويشمل : التخذية، والرعاية، وصحة بيطرية، وتسويق المنتجات الحيوانية.(r) مجال الإنتاج الداجني ويتضمن: تغذية، ورعاية، وصحة بيطرية، وتسويق للإنتاج الداجني. (ع) مجال الغذاء والتغذية ويتضمن: معلومات عن الغذاء الصحي المفيد، ووحفظ وتخزين الخضر والفاكهه، وطريقة طهي وإعداد الطعام من حيث الوصفات والوجبات، والصناعات الغذائية كالمربي والصلصة والمخلات. (0) مجال المشروعات الصغيرة وتتضمن: نوع المشروع الصغير وتكوينه وكذلك تسويق منتجات المشروعات الصغيرة.(7) مجال البيئة والمحافظة عليها وتتضمن: النظافة العامة، ونظافة المنزل وتجميله، وتدوير المخلفات الزراعية.(V) مجال التعليم ويتضمن: تعليم الأبناء، والثئون الددرسية والدراسية. (^) مجال الصحة وإشتمل على: صحة وشئون الأسرة، وعلاج بعض الأمراض، وطرق الوقاية من الأمراض. (9) مجال الأمومة والطفولة ويتضمن:

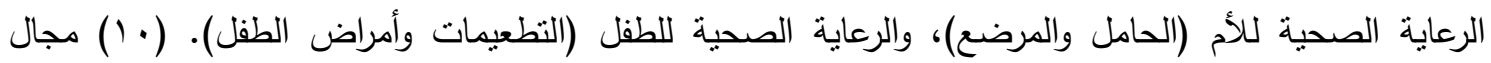
التسويق ويشنمل على: معرفة الأسعار، ومعرفة الأسواق، ومعرفهة وائه أسعار شراء المنتجات، ومعرفة أسعار بيع المنتجات. (1) مجال الثقافة ويتضمن: معرفة المعلومات العامة، ومعرفة المعلومات الدينية مثل القرآن

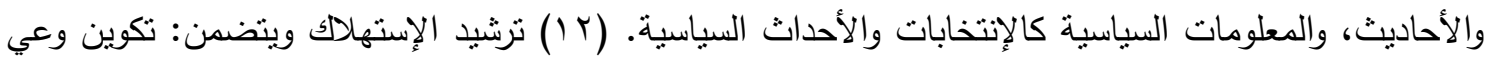
إستهلاكي، والإقتصاد في الوقت والجهد والمال. 
ب- درجة إستخدام المبحوثات للهاتف المحمول في المجالات التنموية: ويقصد به إستخدام المبحوثات للهاتف المحمول في الحصول على المعلومات والمعارف المتعلقة بالمجالات التتموية المدروسة الإثىى عشر ببنودهم الفرعية (0ب بنداً) من حيث عدي مرات الإستخدام أسبوعياً، ومدى الإستخدام. ج- درجة إستفادة المبحوثات من الهاتف المحمول في المجالات التنموية: ويقصد به إستفادة المبحوثات من إستخدام الهاتق المحمول في المجالات التتموية المدروسة من حيث عدد مرات الإستفادة، ومدى الإستفادة. د- دائرة الإتصال المعرفية الهاتفية: ويقصد بها عدد مصادر المعلومات والمعارف التي تحصل منها المبحوثات سواء كونها متصل أو مستقبل على المعلومات التتموية بإستخدامها للهاتف المحمول وهذه تتقمم إلى : (1) المصادر المعرفية الهاتقية للمبحوثات: ويقصد بها عدد المصادر المعرفية التي تتصل بها المبحوثات

$$
\text { للحصول على المعلومات والمعارف (بمن تتصلي) التي تهمها وتفيدها. }
$$

r) مصادر الإتصال بالمبحوثات: ويقصد بها عدد المصادر التي تقوم بالإتصال بالمبحوثات للتواصل

$$
\text { وتزويدها بالعلومات والمعارف (من يتصل بك) التي تهمها وتفيدها. }
$$

\section{r - المتغيرات البحثية وطرق قياسها:}

أولاً: المتغيرات المستقلة

ا - سن المبحوثات: يقصد به سن المبحوثات لأقرب سنة ميلادية. ץ- المستوى التعليمي للمبحوثات: يقصد بها الحالة التعليمية للمبحوثات من حيث كونها: أميه، أو تقرأ وتكتب، أو لونئه أتصت مرحلة تعليمية. وقد نم تصنيفها إلى أميه، وتقرأ ويكتب، تعليم أقل من متوسط، تعليم متوسط، جامعي.

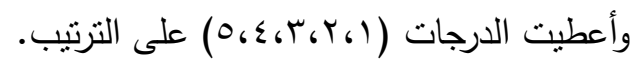
r- المستوى التعليمي للزوج: يقصد بها الحالة التعليمية لأزواج المبحوثات من حيث كونه: أمي، يقرأ ويكتب،

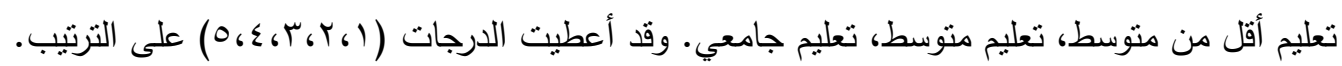
ع - حجم الأسرة: ويقصد به عدد أفراد أسر المبحوثات وقد إستخدم الرقم الخام. ه - المشاركة الإجتماعية: ويقصد بها درجة مشاركة المبحوثات في بعض الأعمال والمشروعات التطوعية بالقرية كمساعدة الأسر المحتاجة، ومشاركة أهل القرية في المناسبات الإجتماعية، وفي مشروعات التتمية بالقرية، معبراً

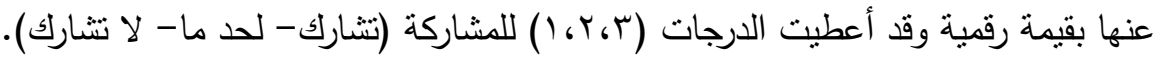
צ- عدد مصادر المعلومات: يقصد بها عدد المصادر المرجعية المعلوماتية التي تستقي منها المبحوثات

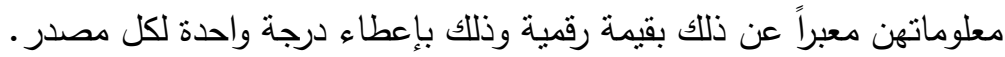
V- التعرض لوسائل الإتصال الجماهيرية: وهو مجموع القيم الرقمية التي حصلت عليها المبحوثات مقابل الإستماع لبرامج الإذاعة، أو مشاهدة برامج التليفزيون، أو قراءة الصحف أو المهلهاتلات سواء بأنفسهن أو من خلال

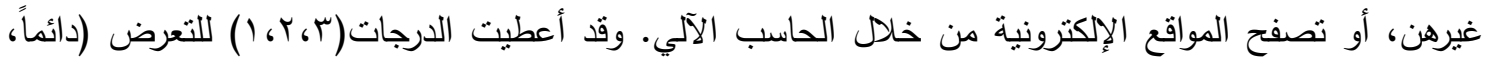

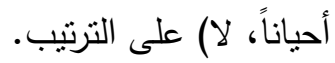
1- التجدية: ويقصد به مجموع القيم الرقمية التي حصلت عليها المبحوثات من خلال إجاباتها على عثر عبارات منها خمس عبارات إيجابية، وخمس عبارات سلبية، تدور حول إستخدام كل ما هو جديد في الأجهزة المنزلية

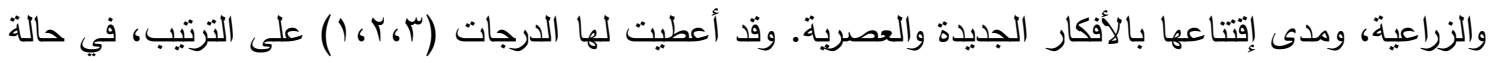
الإجابة (موافق، محايدة، غير موافق) للعبارات الإيجابية والعكس في حالة العبارات السلبية. 
9- القيادية: ويقصد بها درجة قيام المبحوثات بالنصح والمشورة وتقديم المعلومات عن الأمور الأسرية والمنزلية

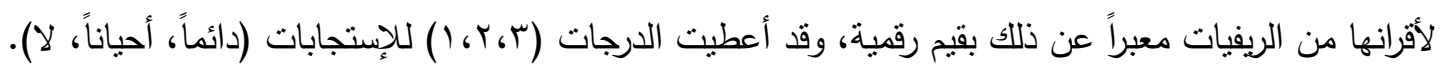

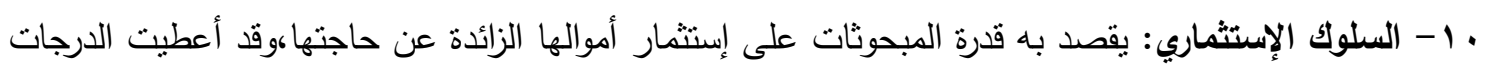

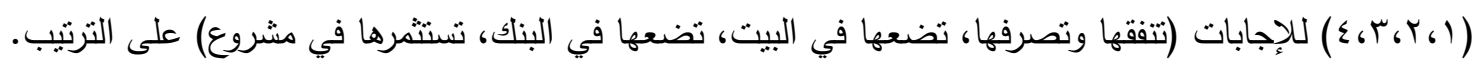
11 - 11

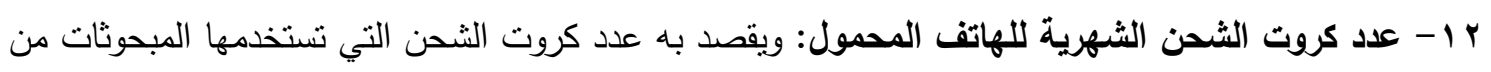
خلال الهاتف المحمول في الثهر. با - مصاريف كروت الثحن الثهرية للهاتف المحمول: ويقصد بها القيم النقية لكروت الثحن الثهرية التي تستخدمها المبحوثات مقدره بالجنية المصري. ـ ا - دافعية إستخدام المبحوثة الهاتف المحمول: يقصد بها الأسباب التي وراء إستخدام المبحوثات للهاتف

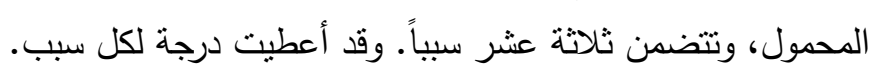
ه - درجة مناسبة الهاتف المحمول لإستخدامات المبحوثات: يقصد بهاته مدى مناسبة الهاتف المحمول

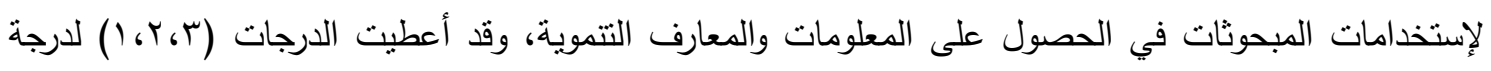

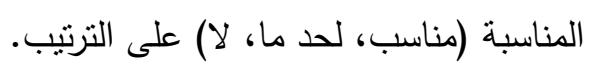
1 ا 1 - المجالات التنموية المفضلة: يقصد بهاعدد المجالات التتموية المفضلة والأكثر تفضيلاً لإستخدام المبحوثات لألات للهاتف المحمول في حصولها على المعلومات والمعارف التتموية، وقد أعطيت درجة لكل مجال.

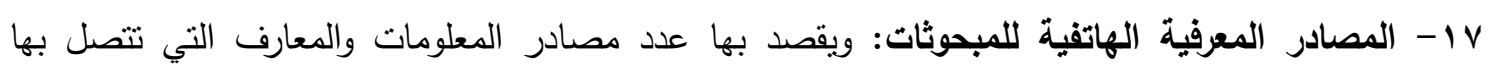
المبحوثات بإستخدام الهاتف المحمول سواء كانت جهات أو أفراد لحصولهن على المعارف والمعلومات التتموية، وقد أعطيت درجة لكل مصدر .

1 1 - مصادر الإتصال بالمبحوثات: ويقصد بها عدد مصادر المعلومات التي تقوم بالإتصال بالمبحوثات بإستخدام

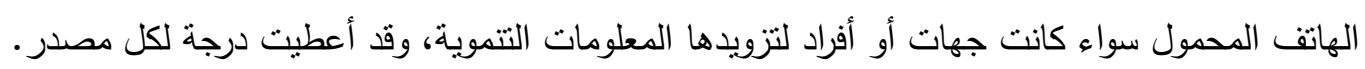
ثانياً: المتغيرات التابعة 1- درجة إستخدام المبحوثات للهاتف المحمول في المجالات التنموية المدروسة: وهو مجموع القيم الرقمية المعبرة عن محورين: أ- عدد مرات الإستخدام: ويقصد بها عدد مرات إستخدام المبحوثات للهاتف المحمول أسبوعياً للحصول على المعلومات والمعارف في المجالات التتموية، وهو رقم خام. وقد نراوحت إجمالي درجات المبحوثات بين (0، 9) مرة أسبوعياً. ب- مدى الإستخدام: وهو يعكس مدى إستخدام المبحوثات للهاتف

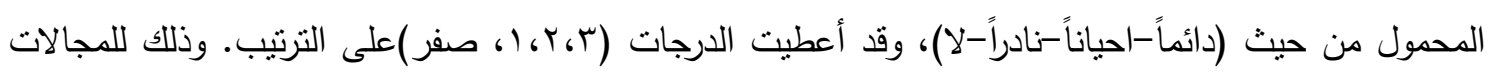

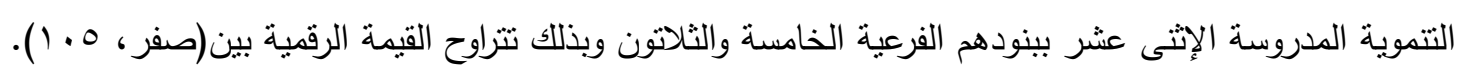

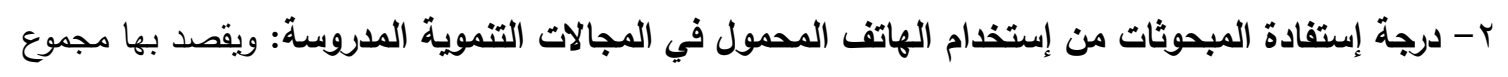

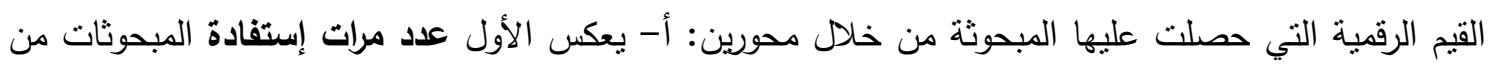
إستخدام الهاتف المحمول في المجالات التتموية المدروسة الأثنى عشر وهو رقم خام. وقد تراوحت إجمالي درجات المبحوثات بين (1 ، • () درجة. بات - مدى الإستفادة: ويقصد به تحديد مدى إستفادة المبحوثة من إستخدام

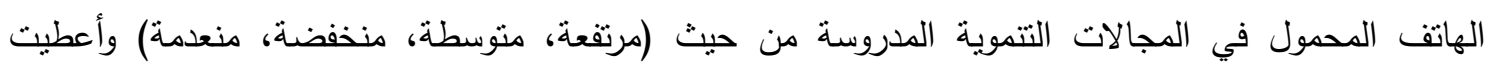

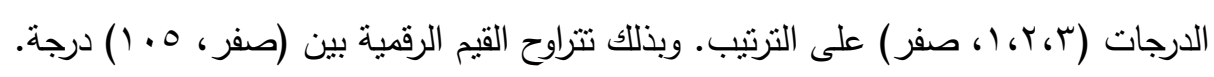


منهج الدراسة: اعتمدت هذه الدراسة على المنهج الوصفي التحليلي. المنطقة البحثية: لقد تحدد المجال الجغرافي في محافظة البحيرة لإجراء هذه الدراسة بإعتبارها من أكبر المحافظات الريفية الزراعية بجمهورية مصر العربية. وتحددت منطقة البحث بإختيار ثلاث مراكز إدارية عشوائياً ثم

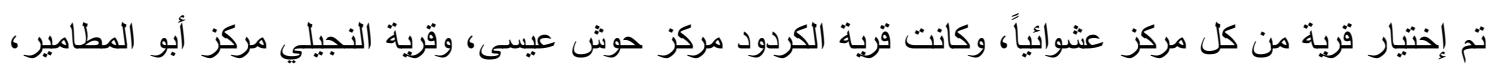

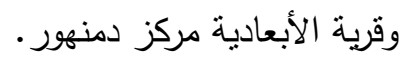

الشاملة والعينة: تم إختيار عينة غرضية من الريفيات المبحوثات (زوجات الزراع) من القرى الثلاث المختارة

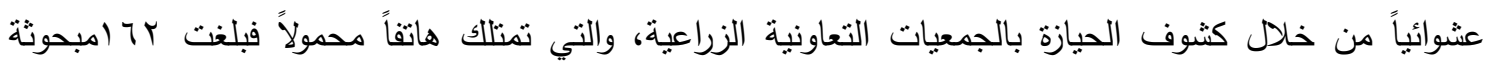

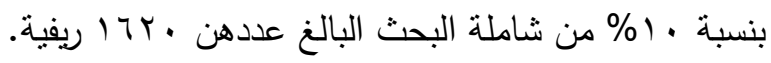
أسلوب جمع البيانات وتحليلها:

تم إستيفاء البيانات البحثية اللازمة لتحقيق أهداف هذا البحث من خلال إستمارة إستبيان تم جمع بياناتها بالمقابلة الثخصية من أفراد عينة البحث بعد إجراء قياس الصدق الظاهري للإستمارة عن طريق عرضها في إني صورتها المبدئية على عشرة محكمين متخصصين في الإرشاد الزراعي والمجتمع الريفي والإقتصاد المنزلي. كما نم

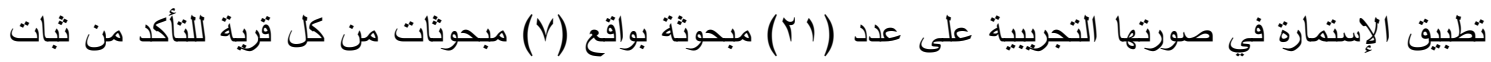
الأداة وتم إجراء التعديلات المطلوبة لتصبح الإستمارة صالحة لتحقيق أهداف الدراسة. وقد الثتملت إستمارة الإستبيان على جزئين اساسين يتضمن الأول: مجموعة من البيانات المتعلقة بالخصائص المميزة للمبحوثات، الهاء

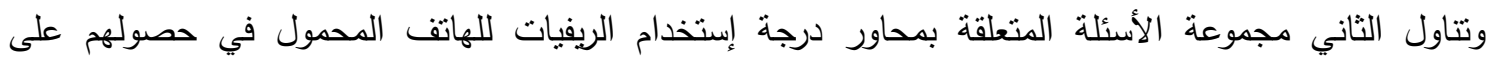

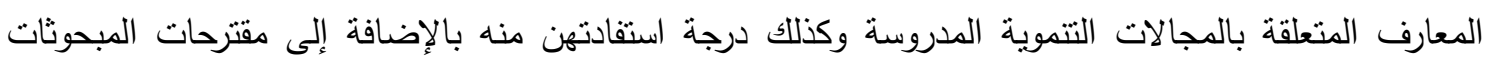
للتغلب على معوقات إستخدام الريفيات للهاتف المحمول والإستفادة منه. ونم تحليل البيانات وعرضها بإستخدام النسب المئوية، والجداول التكرارية، والمنوسط الحسابي، والإنحراف المعياري، ومعامل الإرتباط البسيط والمتعدد، ونموذج التحليل الإنحداري المتعدد التدرجي الصاعد، وإختبار (t)، وإختبار (F).

\section{النتائج البحثية ومناقشتها} أولاً: الخصائص المميزة للمبحثات: تشير النتائج الواردة بجدول (1) إلى الآتي:

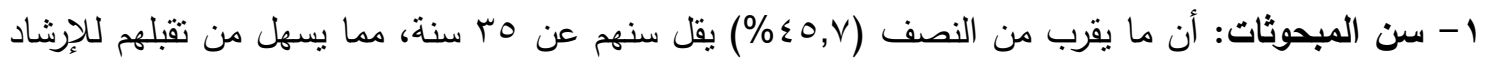
والتوجيه، فضلاً على أنهم يتمتعون بالحيويه والنشاط واكثر إستعداداً لتقبل الأفكار الجديدة.

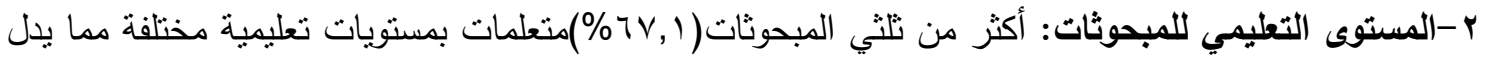
على إرتفاع معدلات إستجاباتهن لإكتساب المعلومات الجديدة والعصرية والإستفادة منها في حياتهن الأسرية.

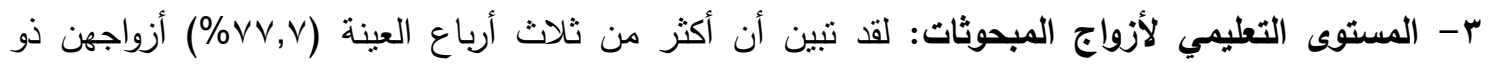
مستويات تعليمية مختلفة مما يعمل على إتاحة الفرصة أمامهم لمساعدة زوجاتهن في إكسابهن المعلومات والمعارف

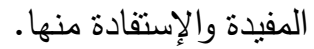




\begin{tabular}{|c|c|c|c|c|c|}
\hline \multicolumn{3}{|r|}{ ن = } & \multicolumn{3}{|c|}{ جدول ( ) توزيع المبحوثات وفقا للخصائص المميزة لهن } \\
\hline$\%$ & عدد & الخصائص & $\%$ & عدد & الخصائص \\
\hline & & 9ـ القيادية: & & & ا - سن المبحوثات: \\
\hline$r, 0$ & rᄉ & منخفضة (أقل من Y I ) درجة & $\varepsilon 0, V$ & $\vee \varepsilon$ & أقل من هب \\
\hline $0 \wedge$, & $9 \leq$ & متوسطة (Y I لأقل من VI I درجة & $\varepsilon r, r$ & $\vee \cdot$ & هب لأقل من ror \\
\hline 11,0 & r. & مرتفعة (V' درجة فأكثر) & 11,1 & 11 & فأكثر Or Or \\
\hline & & • 1 -السلوك الإستثماري: & & & r-الحالة التعليمية للمبحوثات: \\
\hline$\wedge, 7$ & $1 \varepsilon$ & منخفض ( أقل من r) درجة & $r, 1$ & or & منخفض ( اقل من r) درجة \\
\hline $17, \mathrm{~V}$ & $r v$ & متوسطة ( r لأقل من ع) درجات & $\varepsilon r_{.}$. & 71 & منوسط ( r لأقل من 0) درجة \\
\hline$V \leqslant, V$ & $|r|$ & مرتفع (ع درجات) فقط & ro, 9 & $\varepsilon r$ & مرتفع ('م درجات) فأكثر \\
\hline & & I 1 - حيازة الأسرة من الهواتف المحمولة: & & & r-الحالة التعليمية للزوج:ن= r 17 \\
\hline 09,9 & $9 \vee$ & (أقل من ه أجهزة) & r T,r & ז & منخفض ( اقل من r) درجة \\
\hline$r v$, & 7. & (0 لأقل من V أجهزة) & $0 .$, & $\wedge$ & منوسط ( ' لأقل من م) درجة \\
\hline$r, 1$ & 0 & (أجهزة فأكثر V) & $r v, r$ & $\leq 0$ & مرتفع ('0 درجات) فأكثر \\
\hline & & ب ا ـعدد كروت الثحن/ الشهر: & & & ـ ـحجم الأسرة: \\
\hline ( & 1ro & (أقل من ه كروت) & $r, 1$ & or & صغيرة الحجم (أقل من ه أفراد) \\
\hline 17,1 & rt & (0 لأقل من ^ كروت) & $77, \mathrm{~V}$ & $1 \cdot 1$ & متوسطة الحجم (0 لأقل من ^ أفر اد) \\
\hline$\cdot, 7$ & 1 & (^ كروت فأكثر) & $1, r$ & $r$ & كبيرة الحجم (^ أفر اد فأكثر) \\
\hline & & rا ا -مصاريف كروت الثحن/ شهر: & & & هـالمشاركة الإجتماعية : \\
\hline$\wedge \varepsilon$ & די & منخفض ( أقل من VYr) جنية & $17, \mathrm{~V}$ & rV & منخفض ( أقل من Y I) درجة \\
\hline $10, \varepsilon$ & ro & منوسط (Yr لأقل من T97) جنية & $\varepsilon r$, & 71 & متوسط (r الأقل من VI ا درجة \\
\hline$\cdot, 7$ & 1 & مرتفع (9'7 جنية فاكثر) & $\varepsilon 1, r$ & TV & مرتفع (V' ا درجة فاكثر) \\
\hline & & ع ا - دافعية إستخدام الهاتف المحمول: & & & 7.عدد مصادر المعلومات: \\
\hline$r \leq$ & 00 & منخفضة (أقل من ؟) & $r^{1}, 7$ & ro & منخفضة (أقل من 9) مصادر \\
\hline or & $\Lambda \varepsilon$ & منوسطة (ج لأقل من · 1) & 71,1 & 99 & متوسطة (ج لأقل من Y I ) مصدر \\
\hline $1 \varepsilon$ & r & مرتفعة (· ( فأكثر) & IV,r & rA & مرتفعة (r' ( مصدر فأكثر) \\
\hline & & 1 - درجة مناسبة الهاتف المحمول: & & & V- التعرض لوسائل الإتصال الجماهيرية: \\
\hline 71,1 & 99 & مناسب & $q, r$ & 10 & منخفض (أقل من 9) درجات \\
\hline$r \cdot, q$ & $\circ$. & مناسب لحد ما & $\varepsilon \wedge, \wedge$ & $\vee 9$ & منوسط (9 لأقل من ب ( ) درجة \\
\hline$\Lambda, r$ & 14 & غير مناسب & $\varepsilon r$, & 71 & مرتفع (r) درجة فأكثر) \\
\hline & & 7 ا ـأكثر المجالات التنموية المفضلة: & & & ^- التجددية : \\
\hline$r \cdot, q$ & 0. & منخفضة (أقل من 0) مجال & $11, \mathrm{~V}$ & 19 & منخفضة (أقل من سY) درجة \\
\hline 71,1 & 99 & منوسطة (0 لأقل من 9) مجال & $r, r$ & ب & متوسطة (r'Y لأقل من YV) درجة \\
\hline$\wedge$, & ir & مرتفعة (q فأكثر) مجال & 77,1 & $1 \cdot v$ & مرتفعة (rV درجة فأكثر) \\
\hline
\end{tabular}

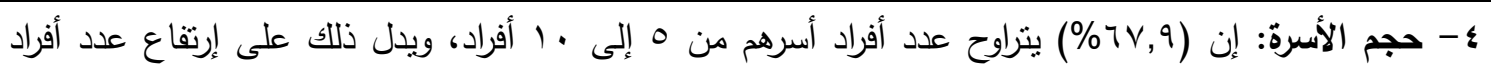
الأسرة، وهذه الصفة سائدة في المجتمع الريفي المصري لحدا كبير نظراً لأهمية قيمة العمل الزراعي العائلي

بجمهورية مصر العربية. ه- المشاركة الإجتماعية: تنين أن ؟,rی\% من المبحوثات من ذوبي المشاركة الإجتماعية المتوسطة والمرتفعة،

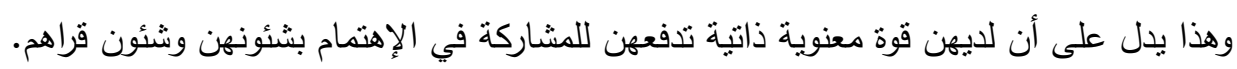

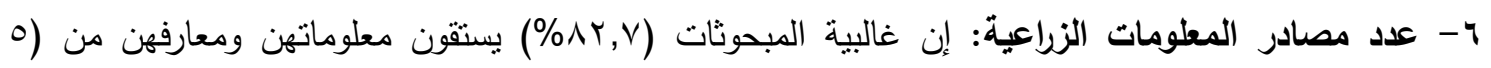

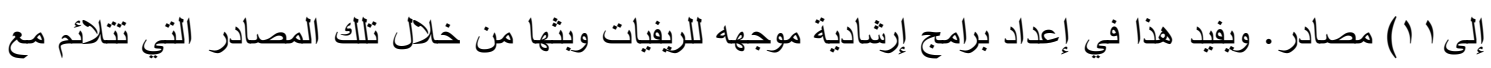
فئاتهن العمرية وإمكانياتهن التعليمية. V- التعرض لوسائل الإتصال الجماهيرية: تبين أن (^, •9\%) مستوى تعرضهن لوسائل الإتصال الجماهيرية مرتفع ومتوسط، مما يتيح لهن فرصة أكبر في زيادة معلوماتهن ومعارفهن والإطلاع على لئل ما يفيدهن في حياتهن. 
1- التجديةة: وجد أن ا, ا77\% من المبحوثات يتمتعن بمستويات تجددية مرتفعة، مما يدل على إرتفاع إستعداد

المبحوثات للتجديد، والأخذ بما هو جديد، والبحث عن مصادر الأفكار الجديدة وما يتصل بها والإقتتاع بها.

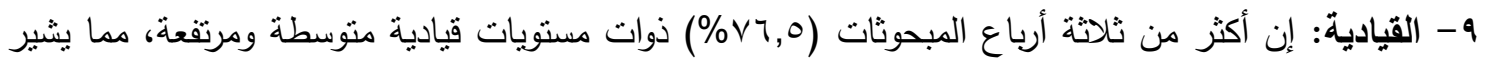

إلى أنهن ذوات ناثير في غيرهن من الريفيات، ومصدر ثقة لديهم في كل ما يقدمون لهن من معلومات ومعارف.

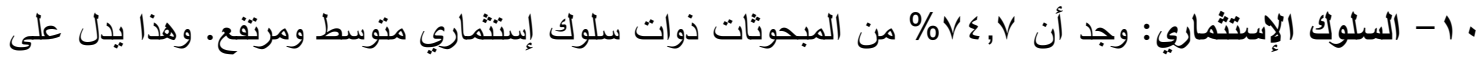
أن المبحوثات يقمن بالإستغلال الأمتل لحد كبير لمواردهم الإقتصادية لتحقيق الإرتقاء بمستوى معيشتهن.

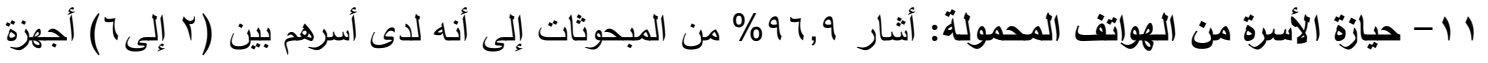
هاتف محمول، مما يشير إلى إنتشار الهاتف المحمول في المجتمع الريفي المصري بالرغم من محدودية دخولهم وهو ما يثير إلى شعور المبحوثات بأهمية الهاتف المحمول في أنشطة حياتهن المختلفة. r ا - عدد كروت الثحن الثهرية للهاتف المحمول: أفاد (؟,99\%) منهن أنهن يستخدمون عدد كروت الثحن من ( إلى V) كارت شحن شهرياً، وهذا يدل على كثرة إستخدام المبحوثات للهاتف المحمول في معظم شئونهن.

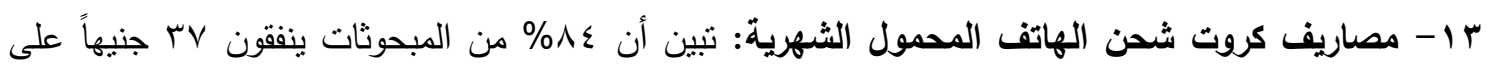
كروت شحن الهاتف المحمول شهرياً.

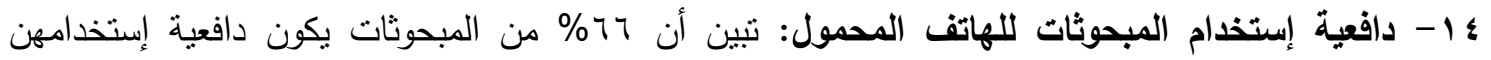

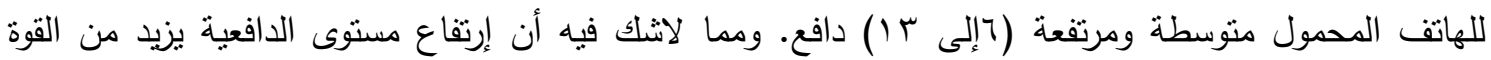
المحركة للإستخدام مما يزيد من فرص إستفادة المبحوثات من الهاتق المحمول. كما توضح نتائج جدول(r) أن دوافع إستخدام المبحوثات للهاتف المحمول ومرتبة نتازلياً وفقاً لتكراراتهن

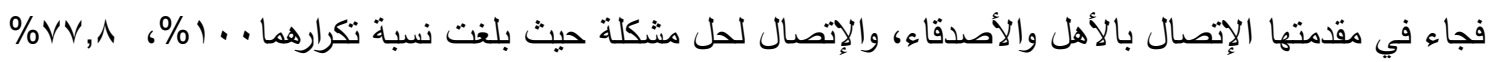
على الترتيب. أما في المراتب الثلاثة الأخيرة فقد جاء إستخدام المبحوثات للهاتف المحمول من أجل المواقع الإلكترونية مثل جوجل، ومواقع البحث العلمي، ومواقع التواصل الإجتماعي Facebook و تويثر ونظام تحديد

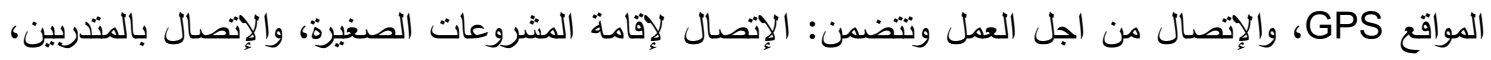
والإتصال للحصول على مدخلات ومنطلبات العمل، وعند بيع المنتجات (لأي المتعاملين مع جهة العمل)، وأخيراً

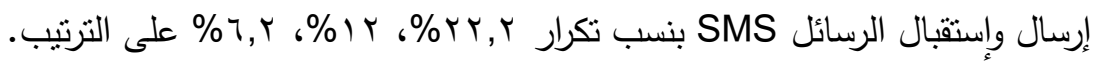
جدول (ץ) توزيع المبحوثات وفقاً لدوافع إستخدامهن للهاتف المحمول

\begin{tabular}{|c|c|c|c|c|c|c|c|}
\hline$\%$ & تكرار & الأوافع & P & $\%$ & تكرار & الأوافع & p \\
\hline$\varepsilon \leqslant, 0$ & VY & إستخدام الكامير اللتصوير & V & $1 \ldots$ & 174 & الإتصال بالأهل و الأصدقاء & 1 \\
\hline ro,, & $0 \wedge$ & التذكير بالمو اعيد & $\wedge$ & $V \vee, \wedge$ & IKT & الإتصال لحل مشكلة ما & r \\
\hline 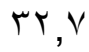 & or & معرفة آخر الأخبار & 9 & vi, & 110 & كمنبه للإستيقاظ & r \\
\hline$r, r$ & ד & إستخدام المو اقع الإلكترونية & 1. & ז". & $1 \cdot r$ & لإكتساب معلومات جديدة & $\varepsilon$ \\
\hline Ir & YI & الإستخدام لأهداف العمل & 11 & 01,9 & $\Lambda \Sigma$ & للإستفسار عن بعض المعلومات & 0 \\
\hline $7, Y$ & 1. & إرسال و إستقبال SMS & Ir & $\leqslant \Lambda, r$ & $\vee \wedge$ & للترفيه & 7 \\
\hline
\end{tabular}

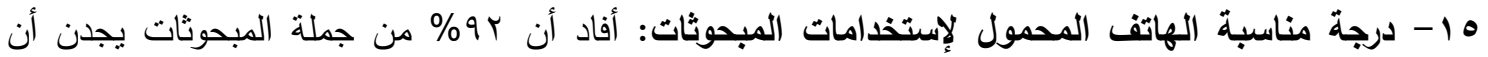

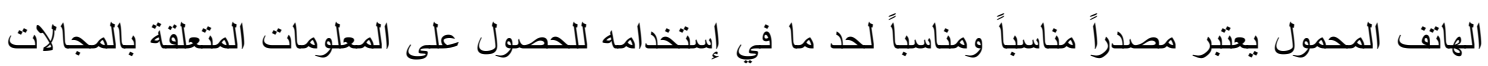
التتموية، وقد أرجعن ذلك لسهولة حصولهن على هذه المعلومات من خلال الإتصال بالمصادر المعلومانية، والخبراء المتخصصين للرد عليهن، ومناسباً في الوقت من حيث طلب المعلومة ومن حيث توقيت إستخدامها، بينما أفاد ؟, \% من المبحوثات بعدم مناسبة الهاتف المحمول للحصول على المعلومات التتموية وقد بررن ذلك بأن بعض المعلومات قد تتطلب المشاهدة ورؤية العين مع السمع. 
צ 1 - المجالات التنموية المفضله لإستخدام الهاتف المحمول: أكد ب9 \% من المبحوثات أنهن يفضلن إستخدام الهاتف المحمول في عدد من المجالات التتموية المدروسة تتراوح بين (1، 9) مجالاً من المجالات التتموية

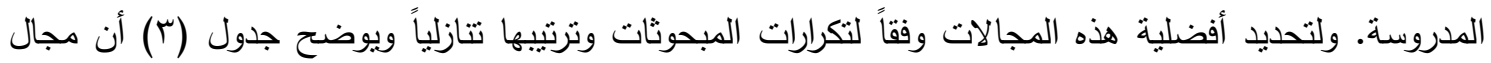

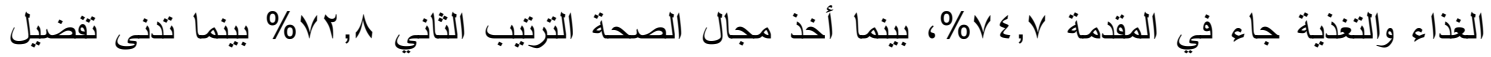

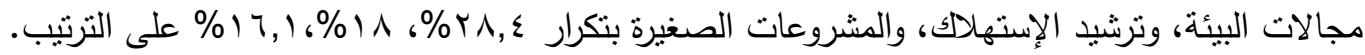
جدول (ץ) توزيع المبحوثات وفقاً للمجالات التنموية المفضله لديهن

\begin{tabular}{|c|c|c|c|c|c|c|c|}
\hline الترتيب & $\%$ & تكرار & المجال & الترتيب & $\%$ & تكرار & ل المجال \\
\hline السابع & $\Gamma \varepsilon$ & 00 & الإنتاج الداجني & الأول & $V \varepsilon, V$ & $|r|$ & الغذاء و التغذية \\
\hline الثامن & $r r, r$ & $0 \leqslant$ & الإنتاج الزر اعي & الثاني & $V Y, \wedge$ & 111 & الصحة \\
\hline التاسع & $r r, v$ & or & الثقافة & الثالث & $v 1,7$ & 117 & التعليم \\
\hline العانشر & r^, \& & $\leqslant 7$ & البيئة & الرابع & $T \leqslant, \wedge$ & 1.0 & الأمو مة و الطفولة \\
\hline الحادي عشر & 11 & rq & ترشيد الإستهلاك & الخامس & $\varepsilon \wedge, \wedge$ & $\vee 9$ & التسويق \\
\hline الثاني عشر & 17,1 & Y & المشروعات الصغيرة & السادس & ro,r & ov & الإنتاج الحيو اني \\
\hline
\end{tabular}

ثانياً: المصادر المعرفية التي تحصل منها المبحوثات على المعلومات التنموية بإستخدام الهاتف المحمول:

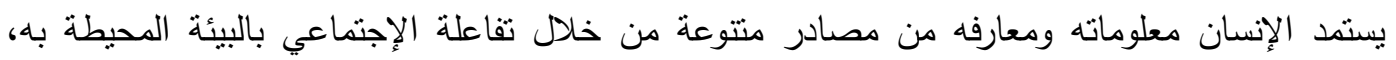

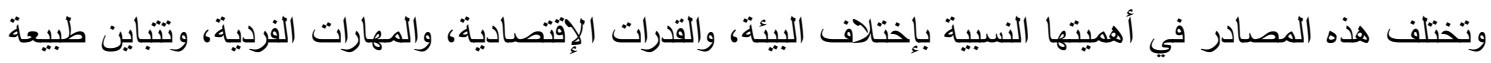
المعارف بتباين المصادر المستقى منها تلك المعارف (الطنوبي ل ...Y، ص:70) وبناء عليه تتقسم المصادر المعرفية المدروسة إلى: 1 - المصادر المعرفيه الهاتقيه للمبحوثات:

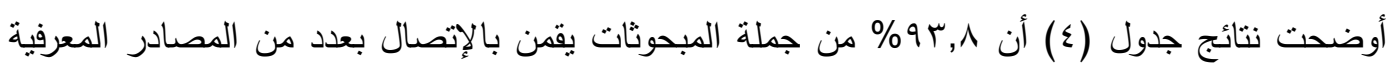

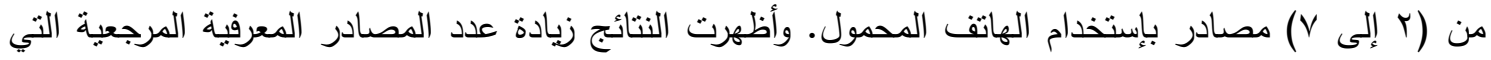
تتصل بها المبحوثات للحصول على المعلومات والمعارف التتموية، مما يثير إلى إقتاع المبحوثات بأهمية الهاتف المحمول كطريقة إتصالية سريعة في الحصول على المعلومات والمعارف بسهولة ويسر ، كما أن لديهن مصداقية وثقه في المصادر المعرفية التي يتصلون بها للحصول على معلوماتهم ومعارفهم التتموية المختلفة، حيث يرى Gamble and Chael (2010, p:9) على توطيد علاقته به والتفاعل معه، وتبادل المعلومات وتطوير الأفكار وإتخاذ القرارات وحل المشكلات.

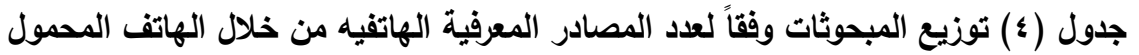

\begin{tabular}{|c|c|c|}
\hline$\%$ & عدد & عدد المصادر المعرفية \\
\hline$\varepsilon \cdot, \mathrm{V}$ & 77 & أقل من 0 مصادر \\
\hline or, & $\wedge 7$ & ه لأقل من ^ مصادر \\
\hline $7, Y$ & 1. & A مصادر فأكثر \\
\hline $1 \ldots$ & $19 r$ & الجملة \\
\hline
\end{tabular}

كما تثير نتائج جدول (0) أن المبحوثات تقمن بالإتصال بمجموعة من المصادر المعرفية سواء كانت جهات أو أفراد بإستخدام الهاتف المحمول للحصول على المعلومات والمعارف المفيدة لها في حياتهن وشئونهن

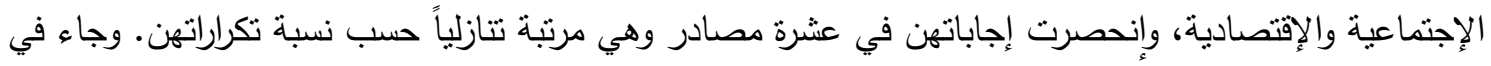

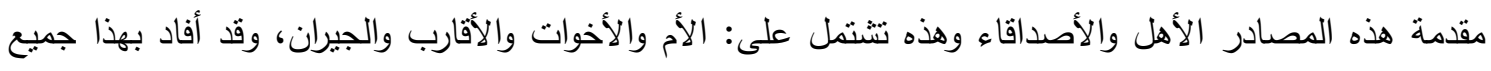
المبحوثات. وجاء بعد ذلك المركز الإرشادي وخاصة المرشدة الزراعية، والوحدة الصحية وخاصة r. r. المبحوثات أن التجار لهم دور مهم كمصدر لمعلوماتهن ومعارفهن من خلال الإتصال بهم عن طريق الهاتف 
المحمول. وقد يرجع ذلك لأنهم الأكثر علماً بأسعار المنتجات الزراعية والحيوانية وغيرها، مما يساعدهن فى عملية

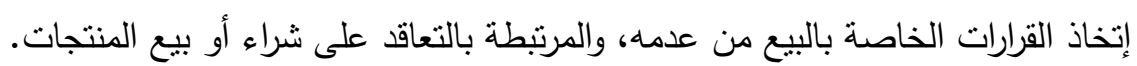

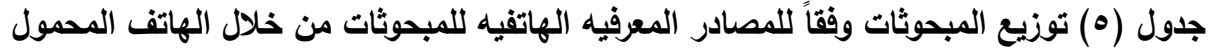

\begin{tabular}{|c|c|c|c|c|c|c|c|}
\hline$\%$ & تكرار & المصدر & م & $\%$ & تكرار & المصدر & 5 \\
\hline$r V, \Lambda$ & $\leqslant 0$ & الجمعية التعاونية الزراعية & 7 & $1 \cdots$ & 174 & الأهل و الأصدقاء & 1 \\
\hline$r V, r$ & $\varepsilon \varepsilon$ & التجار & $\mathrm{v}$ & $V V$ & ITV & المركز الإرشادي & r \\
\hline$r \uparrow, 0$ & $\varepsilon r$ & من في محيط العمل & $\Lambda$ & 07,1 & 94 & الوحدة الصحية " & r \\
\hline 17,1 & rt & القائدات الريفيات & 9 & $\varepsilon \wedge, \wedge$ & $\vee q$ & المدرسة & $\varepsilon$ \\
\hline $7, \wedge$ & 11 & بنك التنمية و الإئتمان الزراعي & 1 . & $r \varepsilon, 7$ & 07 & الوحدة البيطرية & 0 \\
\hline
\end{tabular}

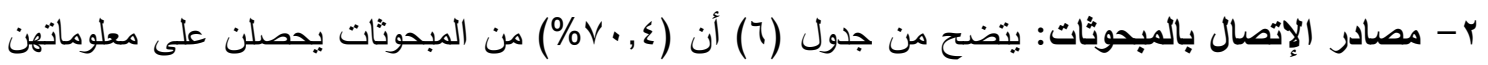

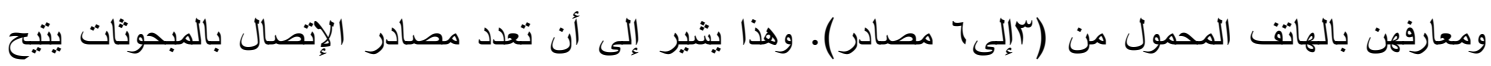
الفرصة أمامهن للحصول على العديد المعلومات والمعارف اللازمة لتوعيتهن وإستفادتهن منها. جدول (آ) توزيع المبحوثات وفقاً لعدد مصادر الإتصال بالمبحوثات من خلال الهاتف المحمول

\begin{tabular}{|c|c|c|}
\hline$\%$ & عدد & عدد المصادر \\
\hline$r q, 7$ & $\varepsilon \wedge$ & أقل من ץ مصادر \\
\hline זים & $1 \cdot r$ & ץ لأقل من ه مصادر \\
\hline$V, \varepsilon$ & Ir & 0 مصادر فأكثر \\
\hline $1 \ldots$ & $17 r$ & الجملة \\
\hline
\end{tabular}

ولما كان التعرف على نوعية المصادر التي تقوم بالإتصال بالمبحوثات من خلال الهاتف المحمول لتزويدها

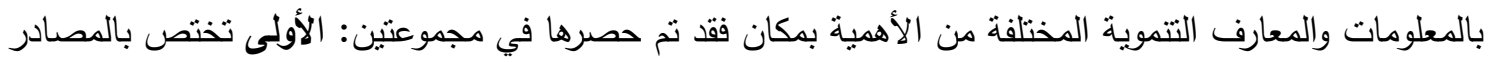

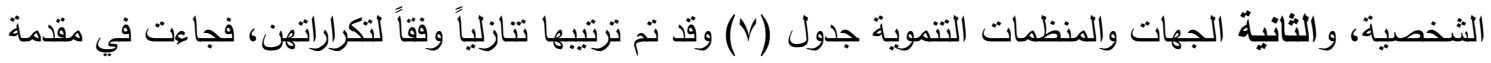
المصادر الثخصية (الأم)، أما الجهات التتموية فقد تصدر المركز الإرشادي خاصة المرشدة الزراعية المرتبة

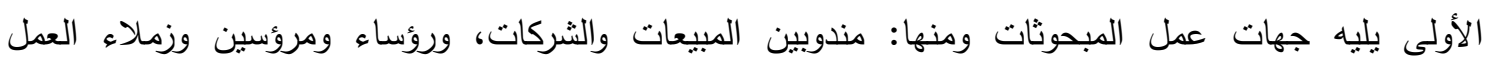

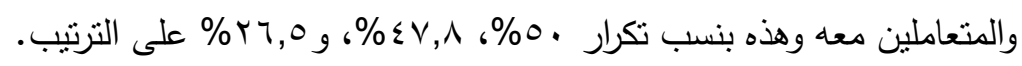

جدول (v) الأهمية النسبية لمصادر الإتصال بالمبحوثات وفقاً لتكراراتهن

\begin{tabular}{|c|c|c|c|c|c|}
\hline$\%$ & تكرار & المصادر الإتصالية & $\%$ & تكرار & المصادر الإتصالية \\
\hline & & r- الجهات التنموية & & & 1- المصادر الثخصية: \\
\hline$\leqslant \vee, \Lambda$ & (1) & ـ المركز الإرشادي & 0. & ᄉ) & ـ الأم \\
\hline$r 7,0$ & $\varepsilon r$ & - جهات عمل المبحوَثات & $r, q$ & or & ـ ـ الأخوات \\
\hline ro, 9 & $\varepsilon r$ & ـ المدرسة ل & $r \wedge, \varepsilon$ & $\varepsilon 7$ & ـ ـ الحماة \\
\hline 19,1 & r & ـ الوحدة الصحية & $r V, r$ & $\varepsilon \varepsilon$ & ـ الجيران \\
\hline$\wedge, 7$ & $1 \leq$ & ـ الجمعية التعاونية الزر اعية & 17,1 & rt & ـ الزوج \\
\hline$r, v$ & ir & ـ الجهات التسويقية( التجار) & $1 \leqslant, \wedge$ & $r \varepsilon$ & - الأبناء \\
\hline$\varepsilon, 9$ & $\wedge$ & ـ الوحده البيطرية ' & $1 \pi, 7$ & rt & ـ الأهل \\
\hline \multirow[t]{2}{*}{ i,r } & r & - بنك التنمية & $9, r$ & 10 & ـ الأصدقاء \\
\hline & & & $\Lambda, 7$ & $1 \varepsilon$ & ـ ـ ـ الأقارب \\
\hline
\end{tabular}

ثالثاً: درجة إستخدام المبحوثات للهاتف المحمول في المجالات التنموية المدروسة: أوضحت النتائج البحثية الواردة بجدول (^) ووفقاً لمحوري قياس درجة إستخدام المبحوثات للهاتف المحمول

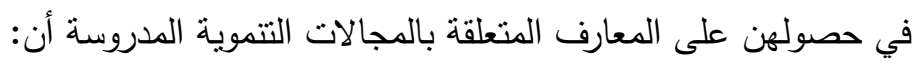

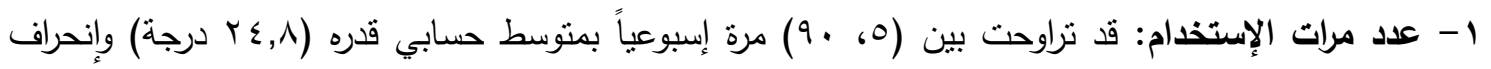

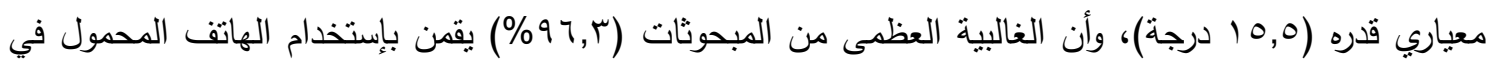

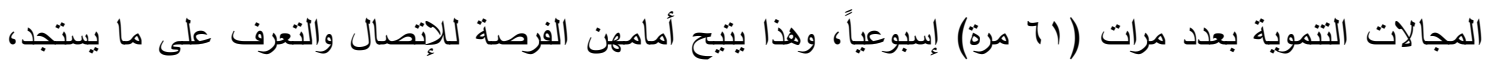


والحصول على معلومات ومعارف أكثر، ولحل مشكلاتهم في حينها، وهو كطريقة إرشادية إتصاليه موثوق فيها للحصول على المعلومات والمعارف من مصدرها. ץ- مدى إستخدام المبحوثات للهاتف المحمول في المجالات التنموية المدروسة: يتراوح بين (r ا، 99 9) درجة

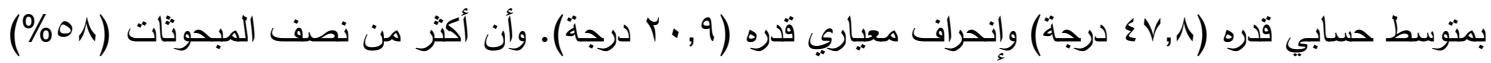
يستخدمن الهاتف المحمول بمدى متوسط ومرتفع. وقد أرجعن ذللك لإتاحته وتوفره في المكان والوقت المناسبين

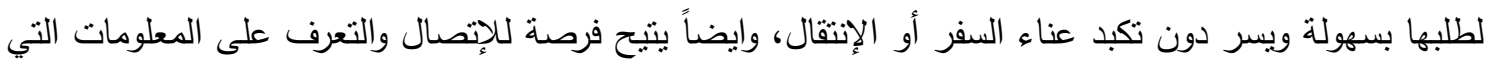

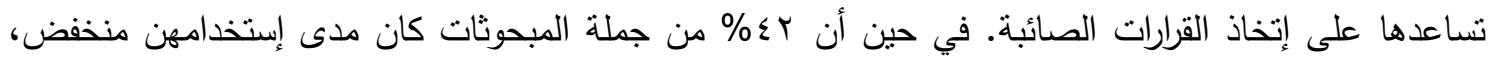
وقد أرجعن ذلك إلى قلة الإمكانيات المادية والفنية للمبحوثات.

جدول (^) توزيع المبحوثات وفقاً لمحوري إستخدامهن للهاتف المحمول في المجالات التنموية

\begin{tabular}{|c|c|c|}
\hline$\%$ & عدد & المحاور \\
\hline & & 1 - علد مرات الأستخدام / الأسبوع: \\
\hline$V \leqslant, V$ & $|r|$ & 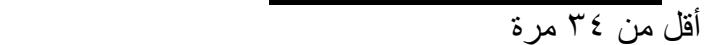 \\
\hline r), & ro & ع الأقل من با مرة \\
\hline r, v & 7 & rاT مرة فأكثر \\
\hline & & ץ-مدى إستخدام الهاتف المحمول في المجالات التنموية: \\
\hline$\varepsilon r$ & 71 & منخفض ( أقل من (؟) درجة \\
\hline$\varepsilon \cdot, \mathrm{V}$ & 77 & منوسط (أ لأقل من •V) درجة \\
\hline IV, r & rA & مرتفع (•V درجة فأكثر) \\
\hline
\end{tabular}

وبناء على ماسبق وفي ضوء قياس محوري درجة إستخدام المبحوثات للهاتف المحمول، أثنارت نتائج

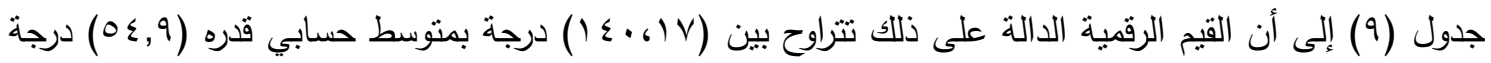

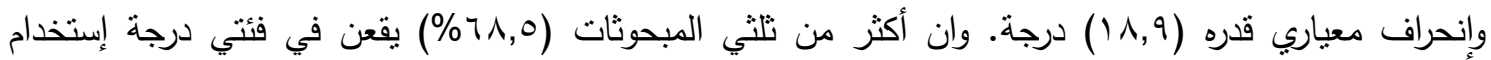
الهاتف المحمول المتوسطة والمرتفعة. مما يدل على الدور الحيوي الذي تقوم به تكنولوجيا الإتصال المتمنله في الهاتف المحمول في حصول المبحوثات على المعلومات والمعارف المتعلقة بالمجالات التتموية المدروسة بسهولة

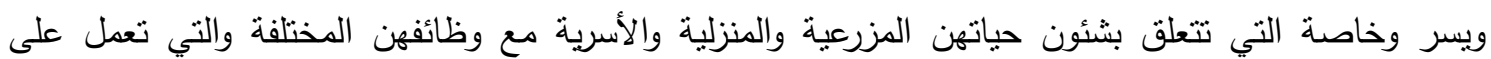
تتميتها وتحسين مستوى معيشتها. حيث أبرز (2003) Richardson أن إختيار تكنولوجيا المعلومات والإتصالات يمكن أن تكون وسيلة فعالة وعملية في تيسير وتوصيل المعلومات. في حين كان 0 , 1ب\% من المبحوثات يقعن في فئة درجة الإستخدام المنخفضة للهاتف المحمول في المجالات التتموية، وقد يعزى ذلك إلى إرتفاع تكلفة إستخدام

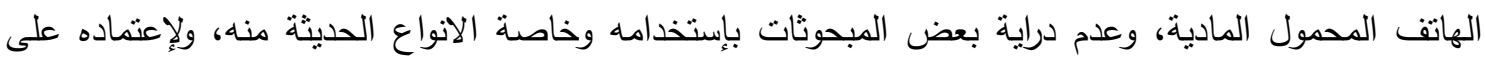
الكلمة المكتوبة مع إنخفاض مستوى تعليم بعضهن. جدول (9) توزيع المبحوثات وفقاً لارجة إستخدام للهاتف المحمول في المجالات التنموية المدروسة

\begin{tabular}{|c|c|c|}
\hline$\%$ & عدد & الفئات \\
\hline$r, 0$ & 01 & منخفض (أقل من مه) درجة \\
\hline $0 \cdot, \cdot$ & 人) & متوسطة (1) لأقل من 99) درجة \\
\hline 11,0 & r. & مرتفعة (9 9 درجة فأكثر) \\
\hline $1 \ldots$ & $17 r$ & الجملة الم الم \\
\hline
\end{tabular}

كما تثير النتائج البحثية بجدول (ب ا) إلى أن درجة إستخدام المبحوثات للهاتف المحمول تختلف من مجال تتموي لآخر من المجالات التتموية المدروسة فنجد أن مجال الغذاء والتغذية نال أكبر درجة إستخدام، يليه مجال

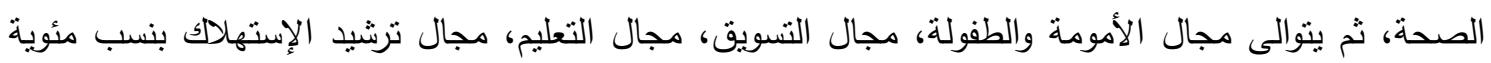

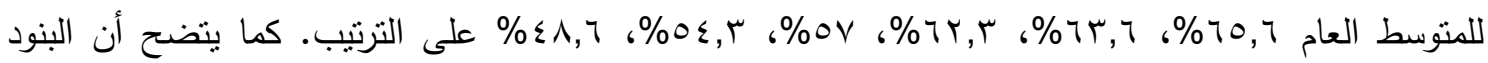


المتضمنة للمجالات التتموية المدروسة الأكثر إستخداماً قد جاء في مقدمتها حفظ وتخزين وسلامة الغذاء، طرق

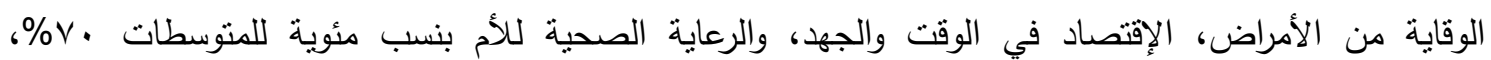

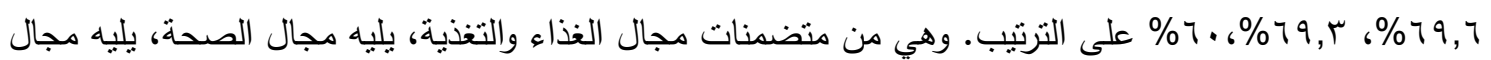

$$
\text { ترشيد الإستهلاك، فمجال الأمومة والطفولة على التوالي. }
$$

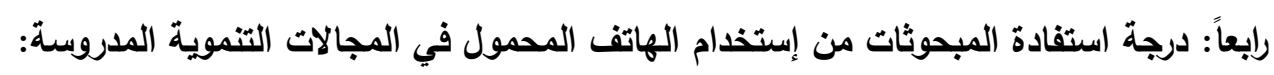

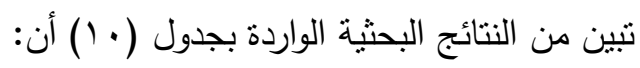
أ- عدد مرات إستفادة المبحوثات: من إستخدام الهاتف المحمول نتراوح ما بين (1، (1) • (1) مرات بمنوسط حسابي

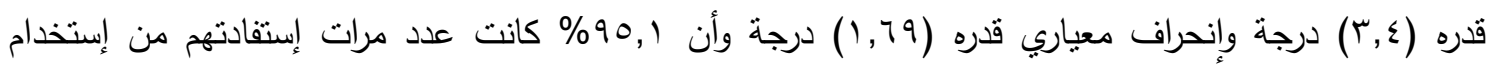

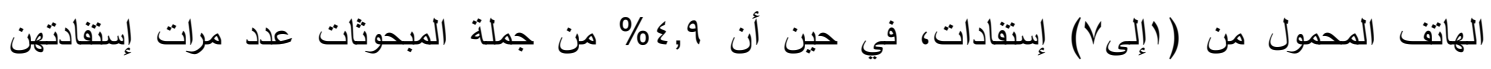

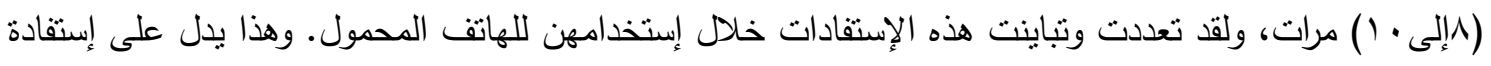
المبحوثات وتطبيق ما تحصل عليه من معلومات ومعارف لتحقيق أقصى إستفادة ممكنه.

\begin{tabular}{|c|c|c|}
\hline$\%$ & عدد & المحاور \\
\hline & & 1 - عدد مرات الاستفادة: \\
\hline$\Delta r, 1$ & سז & (أقل من ه مرات) \\
\hline $1 \%$ & $r_{1}$ & (' لأقل من ^ ) مرات \\
\hline$\varepsilon, 9$ & $\wedge$ & ( ( مر ات فأكثر ) \\
\hline & & ז- مدى الإستفادة: \\
\hline$r \cdot, \wedge$ & 0 . & منخفض ( أقل من بr ) درجة \\
\hline$\varepsilon \wedge, \wedge$ & $\vee q$ & منوسط (Tَء لأقل من اV) درجة \\
\hline$r \cdot, \varepsilon$ & سז & مرتفعة (' ل فأكثر) درجة \\
\hline
\end{tabular}

وقد تمثلت هذه الإستفادات حسب تكرار المبحوثات بإجمالي (Y (T)) إستفادة وهي كما يلي بجدول (1) (1):

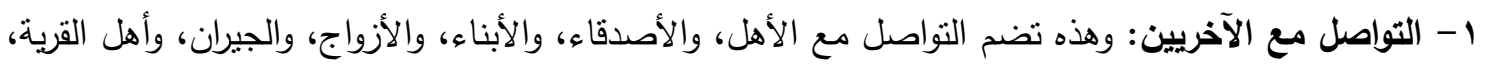

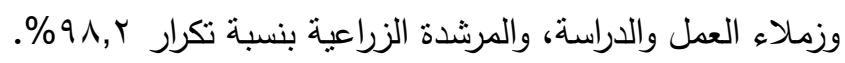

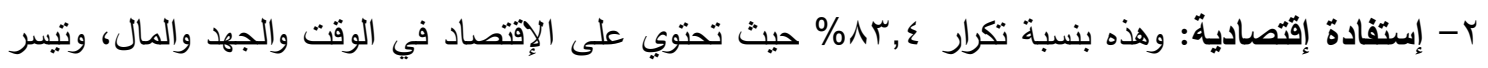

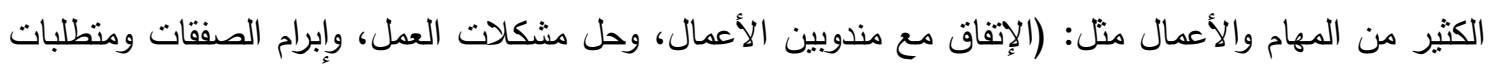

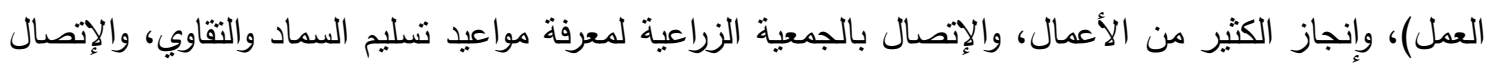
بالمرشدات الزراعية لمعرفة كيفية عمل المشروعات الصغيرة مثل: تربية الأرانب، والصابون السائل، وتسمين

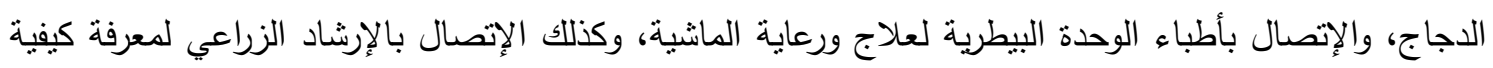

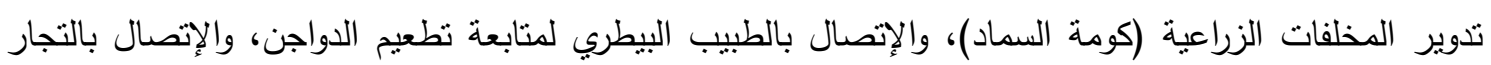

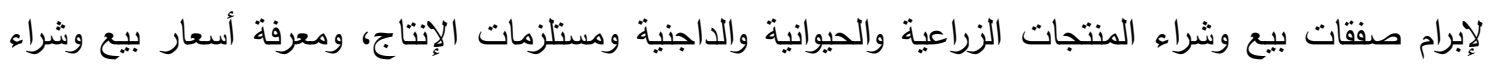
المنتجات بالأسواق، وأسعار الجملة. r- الإستفادة المعرفية التثقيفية: ومنها: الإستفادة كمنبهات لمعرفة الوقت والمواعيد والتذكر، والحصول على المعلومات التثقيفية، والمعلومات الدينية، والمعلومات العامة والسياسية، وحل الكثير من المشكلات، والتصوير ،

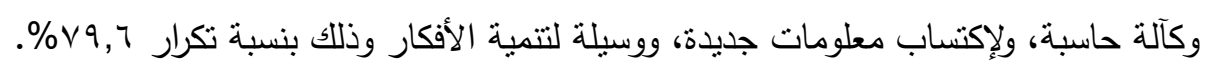

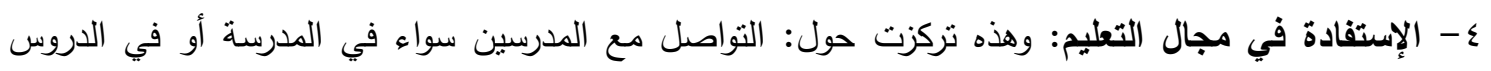
الخصوصية، متابعة الأولاد في المدرسة وفي الدروس الخصوصية، والإتصال للإستفسار عن الأمور المدرسية 
كالإتصال بإدارة المدرسة، والإتصال بأولياء أمور الطلبة، والإتصال بالمدرسين والدارسين في فصول محو الأمية.

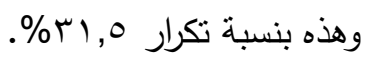

ه- الإستفادة في مجال الغذاء والتغذية: وهذه احتوت على الإتصال للتعرف على تصنيع الوجبات الغذائية،

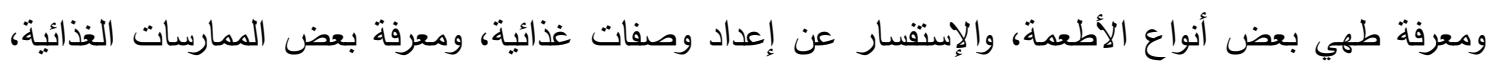

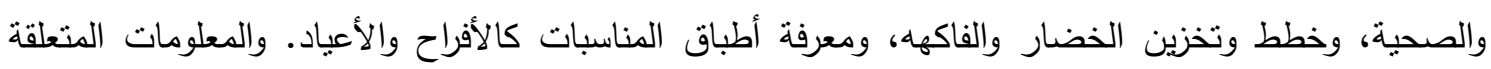

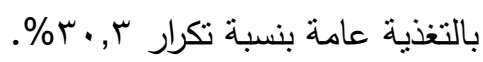
צ- الإستفادة في مجال الصحة: ومنها: الإتصال بالأطباء لمتابعة صحة الأولاد، وعند الحاجة إليهم، الإتصال

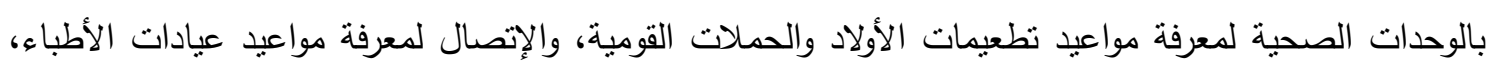

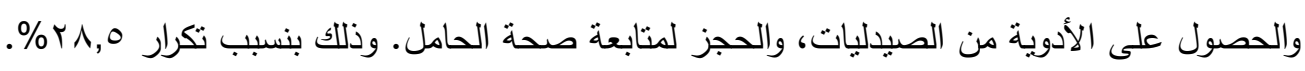

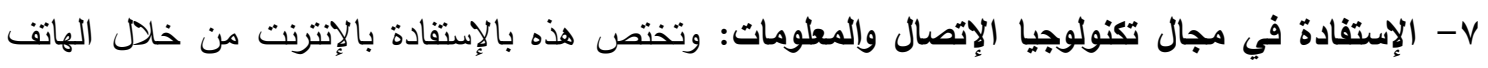

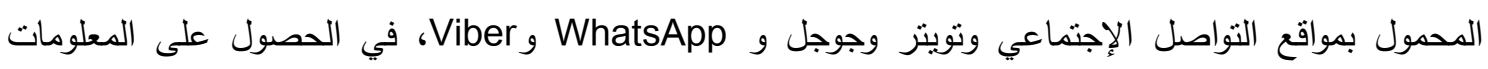
والمعارف ومحركات البحث العلمي المفيدة (جعل العالم قرية صغيرة فهو وسيلة لربط العالم)، ومعرفة الأخبار أولاً

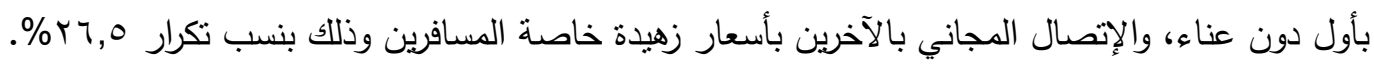

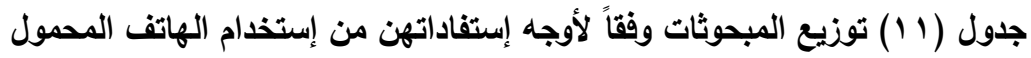

\begin{tabular}{|c|c|c|c|c|c|}
\hline$\%$ & تكرار & أوجه الإستفادة & $\%$ & تكرار & أوجه الإستفادة \\
\hline$r \cdot, r$ & $\leqslant 9$ & هـ الإستفادة في مجال الغذاء و التغذية & $9 \wedge, Y$ & 109 & 1 ـالتو اصل مع الأخرين. \\
\hline$r \Lambda, 0$ & $\leqslant 7$ & ؟-الإستفادة في مجال الصحة. & $\Lambda r, \varepsilon$ & 1ro & r-الإستفادة الإقتصادية. \\
\hline$r 7,0$ & $\varepsilon r$ & V-الإستفادة في مجال تكنولوجيا & $\vee q, 7$ & $1 \mathrm{rq}$ & ك-الإستفادة المعرفية التثقيفية. \\
\hline & & المعلومات. & r1,0 & 01 & ـ ـ-الإستفادة في مجال التعليم. \\
\hline
\end{tabular}

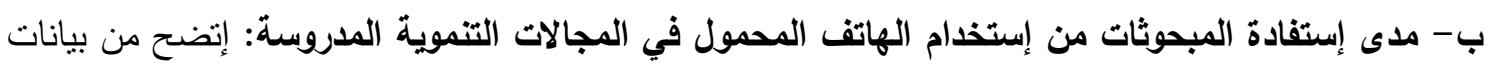
جدول (•) أن مدى إستفادة المبحوثات من إستخدام الهاتف المحمول في المجالات التتموية المدروسة نتراوح

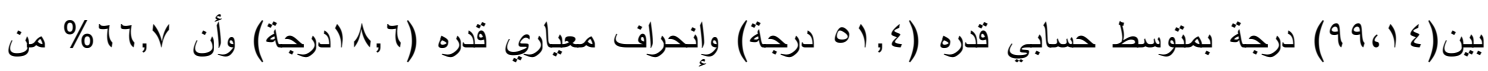

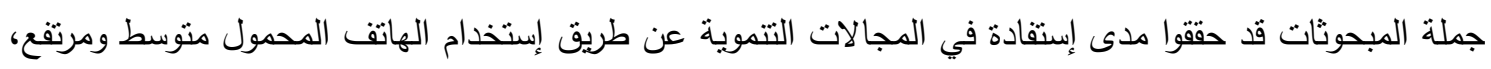
وكانت منخفضة لدى بr\% من جملة المبحوثات. وبناء على ماسبق وفي ضوء محكات قياس درجة إستفادة المبحوثات من إستخدام الهاتف المحمول في

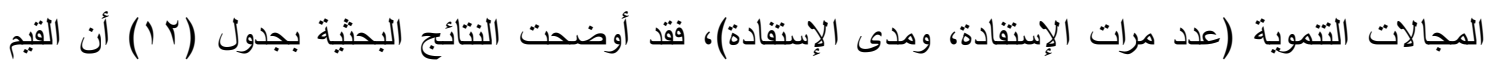

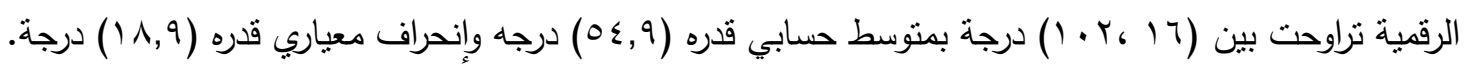

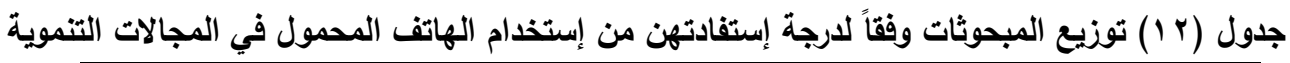

\begin{tabular}{|c|c|c|}
\hline$\%$ & عدد & فئات الإستفادة \\
\hline$r \cdot, \wedge$ & 0. & منخفض (أقل من 0؛) درجة \\
\hline$\varepsilon \wedge, \wedge$ & $\vee q$ & متوسط (0 ك لأقل من ؟ V) درجة \\
\hline$r \cdot, \Sigma$ & 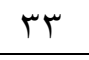 & مرتفعة (ع V درجة فأكثر) \\
\hline $1 \ldots$ & $17 r$ & الجملة \\
\hline
\end{tabular}

وأن نسبة المبحوثات اللاتي تنتفدن بدرجة مرتفعة ومتوسطة ب,79\%، وهذا يعني إستفادة المبحوثات من

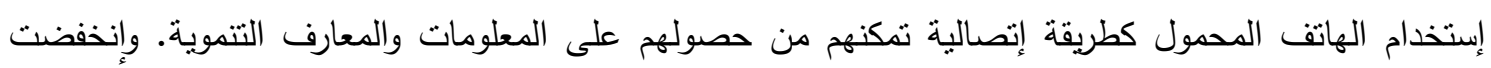

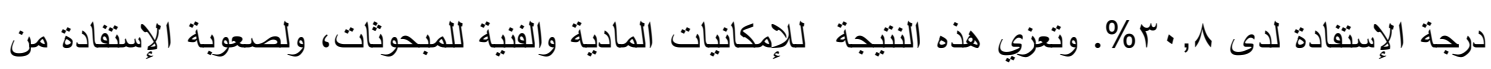
الهاتف المحمول خاصة الأنواع الحديثة منه. 
ويوضح جدول (r آ) أن مجالات الغذاء والتغذية، والأمومة والطفولة، والصحة هم أهم الهجالات التي

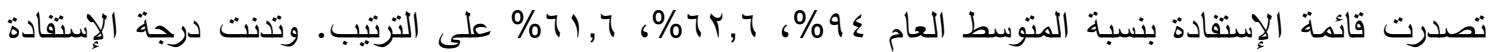
مجالي الإنتاج الحيواني والمشروعات الصغيرة بنسبة rr\%، r, r \% على الترتيب.

جدول (r I) المجالات التتموية وفقاً لمتوسط درجة إستخدام المبحوثات للهاتف المحمول ودرجة إستفادتهن منه

\begin{tabular}{|c|c|c|c|c|c|c|}
\hline \multicolumn{3}{|c|}{ درجة الإستفادة } & \multicolumn{3}{|c|}{ درجة الإستخدام } & \multirow{2}{*}{ المجالات التنموية } \\
\hline الترتيب & $\%$ & المتوسط & الترتيب & $\%$ & المتوسط & \\
\hline \multirow{4}{*}{ الثامن } & & & العاشر & & & 1-الإنتاج الزراعى: \\
\hline & 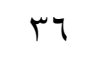 & $1, \cdot 1$ & & r, זr & 1 & - زراعة بعض المحاصيل \\
\hline & ro & 1,0 & & T & • & ـ تسويق المحاصيل \\
\hline & ro,r & 1,7 & & rt & $\cdot, 97$ & المتوسط العام \\
\hline \multirow{6}{*}{ الحادي عشر } & & & الإثنى عشر & & & r-الإنتاج الحيوانى: \\
\hline & $r \wedge, 7$ & $\cdot, \wedge 7$ & & rT, & $\cdot, V_{1}$ & - تغذية \\
\hline & ro,r & $1, \cdot 7$ & & 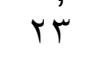 & $\cdot, 97$ & - رعاية \\
\hline & r人 & $1,1 \varepsilon$ & & ґᄉ & $1,1 \varepsilon$ & - صحة بيطرية \\
\hline & $r, r q$ & $\cdot, \vee 9$ & & 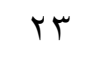 & $\cdot, \mathrm{V}$ & - تسويق \\
\hline & Tr & $\cdot, 97$ & & $\cdot, 77$ & $\cdot, \cdot r$ & المتوسط العام \\
\hline \multirow[t]{6}{*}{ التاسع } & & & التاسع & & & ب-الإنتاج الاج(جني: \\
\hline & r), & $\cdot, 90$ & & rY,T & $\cdot, 91$ & - تغذية \\
\hline & $r \varepsilon, r$ & $1, \cdot r$ & & $r \varepsilon, r$ & $1, \cdot r$ & - رعاية \\
\hline & $\varepsilon \cdot, 7$ & $1, Y Y$ & & $\varepsilon$ & $1, r$ & - صحة بيطرية \\
\hline & ro,r & $\cdot, V_{7}$ & & $r_{0,7}$ & $\cdot, \mathrm{VV}$ & - تسويق \\
\hline & مُنَ & $\cdot, 99$ & & سُب & $\cdot, 99$ & المتوسط العام \\
\hline \multirow[t]{6}{*}{ الأول } & & & الأول & & & ـ ـ- الغذاء و التفذيةة: \\
\hline & ᄉ), r & $r, \varepsilon \varepsilon$ & & $\leqslant q, r$ & $1, \wedge \varepsilon$ & - مواصفات الغذاء الصحي \\
\hline & $\wedge$. & $r, \varepsilon$ & & $v \cdot$ & $r, 1$. & - حفظ وتخزين الأغذية \\
\hline & $v\urcorner, r$ & $r, r q$ & & $70, r$ & 1,97 & ـ طرق طهي وإعداد الطعام \\
\hline & $7 \wedge, 7$ & $r, \cdot r$ & & r, & 1,99 & ـ الصناعات الغذائية \\
\hline & $9 \varepsilon$ & r,Ar & & 70,7 & $1,9 \vee$ & المتوسط العام \\
\hline \multirow[t]{4}{*}{ الثاني عشر } & & & الحادس عشر & & & هـ المشروعات الصغيرة: \\
\hline & $r \cdot$ & $\cdot, 9$. & & ir,r & $\cdot, \mathrm{V}$ & - نوع وتكوين المشروع \\
\hline & rt & $\cdot, 97$ & & r & $\cdot, 79$ & ـ تسويق الإنتاج \\
\hline & $r\urcorner, r$ & $\cdot, \mathrm{\vee} 9$ & & $r r, T$ & $\cdot, \mathrm{V}_{1}$ & المتوسط العام \\
\hline \multirow[t]{5}{*}{ العاشر } & & & ال الثامن & & & 7- البيئةة: \\
\hline & ro & $\cdot, \vee_{0}$ & & r & $\cdot, 9 \vee$ & ـ النظافة العامة للك و لأسرتك \\
\hline & $\Gamma \varepsilon$ & $1, \cdot r$ & & $r \varepsilon, 7$ & $1, \cdot \varepsilon$ & ـ نظافة المنزل وتجميله \\
\hline & $r q, 7$ & 1,19 & & $\leqslant 1$ & 1, & ـ تدوير المخلفات الزر اعية \\
\hline & r r & $\cdot, 9 \wedge$ & & 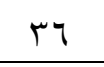 & $1,1 \cdot 1$ & المتوسط العام عل \\
\hline \multirow[t]{4}{*}{ 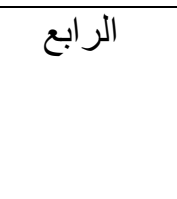 } & & & الخامس & & & V- التعليم: \\
\hline & 7. & $1, \wedge$. & & 00 & 1,70 & ـ تعليم الأبناء \\
\hline & $07, r$ & 1,79 & & $0 \leqslant$ & $1,7 r$ & ـ ـ الشئون المدرسية \\
\hline & $0 \wedge$ & $1, v \varepsilon$ & & $0 \leqslant, r$ & $1,7 \pi$ & المتوسط العام \\
\hline \multirow[t]{5}{*}{ 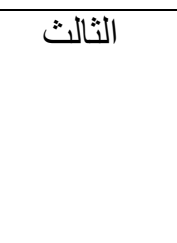 } & & & 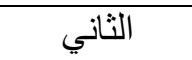 & & & ^- الصحةة: \\
\hline & 01 & 1,0 r & & 09,7 & $1, \times 9$ & ـ صحة وشئون الأسرة. \\
\hline & $7 \varepsilon$ & $1,9 r$ & & 71,7 & 1,10 & ـ علاج بعض الأمر اض. \\
\hline & $v \cdot$ & $r, 1$ & & 79,7 & $r, \cdot 9$ & ـ طرق الوقاية من الأمر اض. \\
\hline & 71,7 & 1,10 & & T & 1,91 & المتوسط العام \\
\hline
\end{tabular}


تابع جدول (r ا ) المجالات التنموية وفقاً لمتوسط درجة إستخدام المبحوثات للهاتف المحمول ودرجة إستفادتهن منه

\begin{tabular}{|c|c|c|c|c|c|c|}
\hline \multicolumn{3}{|c|}{ درجة الاستفادة } & \multicolumn{3}{|c|}{ درجة الإستخدام } & \multirow[t]{2}{*}{ المجالات التنموية } \\
\hline الترتيب & $\%$ & المتوسط & الترتيب & $\%$ & المتوسط & \\
\hline \multirow{4}{*}{ الثاني } & & & الثالث & & & 9- أمومة وطفولة: \\
\hline & $T r, T$ & $1, \wedge \Lambda$ & & 7. & 1,1 & ـ الرعاية الصحية للام. \\
\hline & $7 r, 7$ & $1, \wedge \wedge$ & & $0 \wedge, 7$ & $1, \vee_{7}$ & ـ الرعاية الصحية للطفل \\
\hline & $7 r, 7$ & $1, \wedge \wedge$ & & r', & $1, \wedge \vee$ & المتوسط العام " \\
\hline \multirow[t]{6}{*}{ السادس } & & & 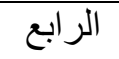 & & & • 1 - التسويق: \\
\hline & r & 1,7 & & $0 ., 7$ & $1,0 \mathrm{r}$ & - معرفة الأسعار \\
\hline & $\varepsilon v$ & $1, \leqslant 1$ & & $\varepsilon \dot{v}$ & $1, \leqslant 1$ & ـ معرفة السواق - \\
\hline & $\leqslant 0,7$ & $1, r V$ & & $\leqslant 0, r$ & $1,1,4$ & ـ معرفة اسعار شر اء المنتجات \\
\hline & $\varepsilon 7, r$ & ( & & $\varepsilon r$ & $1, r q$ & ـ معرفة اسعار بيع المنتجات \\
\hline & $\varepsilon \wedge$ & $1, \leqslant \varepsilon$ & & ov & $1, \times 1$ & المتوسط العام \\
\hline \multirow[t]{5}{*}{ الخامس } & & & 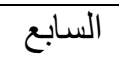 & & & | 1 - الثقافة \\
\hline & 0 & 1,0 & & $\{\wedge, 7$ & $1, \leqslant 7$ & ــ المعلومات العامة. \\
\hline & $0 \leqslant, 7$ & $1,7 \varepsilon$ & & $0 \cdot, r$ & 1,01 & ـ المعلومات الدينية \\
\hline & or & 1,07 & & ro,r & $\cdot, \mathrm{VT}$ & ـ المعلومات السياسية \\
\hline & or & 1,07 & & $\varepsilon 1, r$ & $1, Y \varepsilon$ & المتوسط العام \\
\hline \multirow[t]{4}{*}{ السابع } & & & السادس & & & r ا - ترشيد الإستهلاك: \\
\hline & rq & $\cdot, \wedge \vee$ & & rᄉ & $\cdot, \wedge \varepsilon$ & ـ تكوين وعي إستهلاكي(شر اء ما يلزمك) \\
\hline & $77, r$ & 1,99 & & $79, r$ & $r, \wedge$ & ـ الإقتصاد في الوقت والجهد والمال. \\
\hline & $\varepsilon \vee, T$ & $1, \varepsilon r$ & & $\varepsilon \wedge, 7$ & $1, \leqslant 7$ & المتوسط العام" \\
\hline
\end{tabular}

وأن أكثر بنود المجالات التتموية المدروسة إستفادة هي: مواصفات الغذاء الصحي، وحفظ وتخزين وسلامة

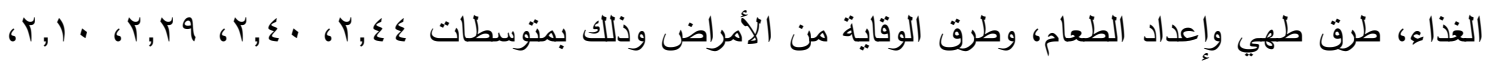

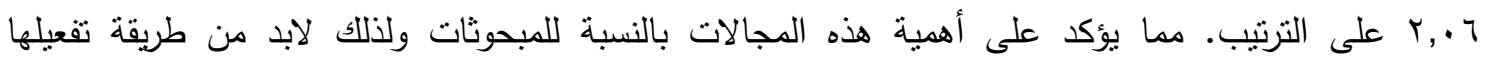

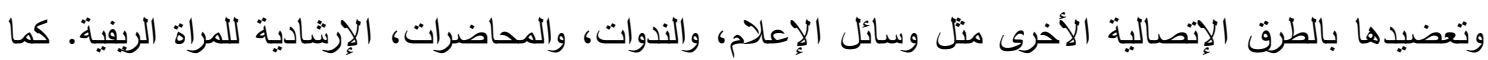
إتضح وجود مجالات كانت درجة الإستفادة منها دون الهدف المنشود وتمثلت في مجال المشروعات الصغيره،

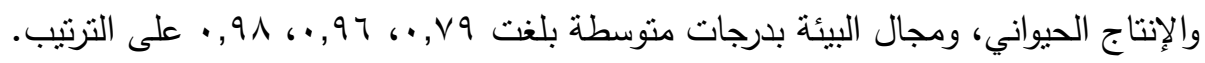
خامساً: أ- العلاقات الإرتباطية والإنحدارية بين المتغيرات المستقلة المدروسة ودرجة إستخذام المبحوثات للهاتف المحمول في المجالات التموية المدروسة كمتغير تابع: يتضح من جدول (ع ( ) مايلي:

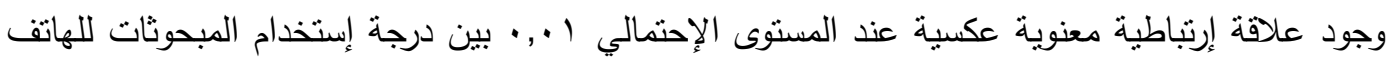
المحمول في المجالات التتموية كمتغير تابع وسن المبحوثة. كما تبين وجود علاقة إرتباطية طردية معنوية عند الإندية

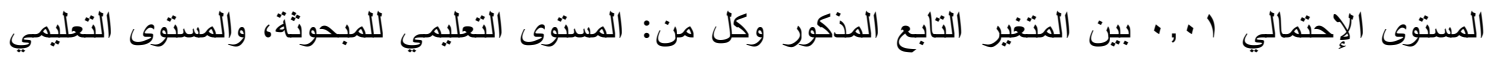

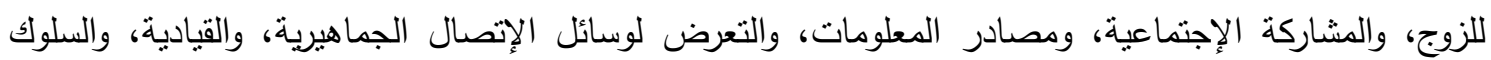

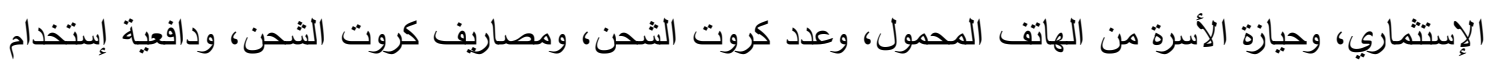

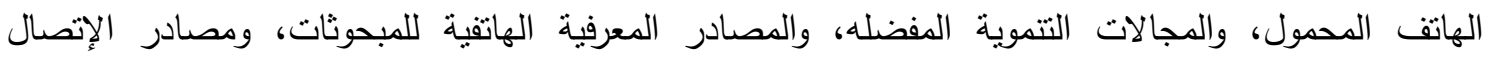
بالمبحوثات، ودرجة الإستفادة من الهاتق المحمول. ووجود علاقة إرتباطية طردية معنوية عند المستوى الإحتمالي ه. . • بين هذا المتغير التابع ودرجة مناسبة الهاتف المحمول. في حين لم تتبت معنوية العلاقة بين هذا المتغير التابع والمتغيرات المستقلة المدروسة. 
وبناء على هذه النتائج فإنه يمكن قبول الفرض البحثي الأول جزئياً بالنسبة للمتغيرات المستقلة المدروسة

التي ثبت أن لها علاقة معنوية بالمتغير التابع المذكور، ورفضه بالنسبة لباقي المتغيرات المستقة المدروسة.

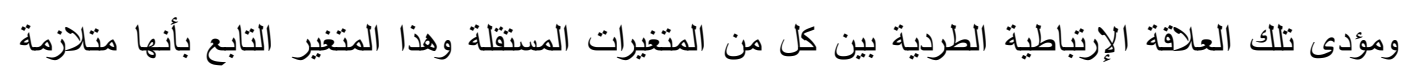

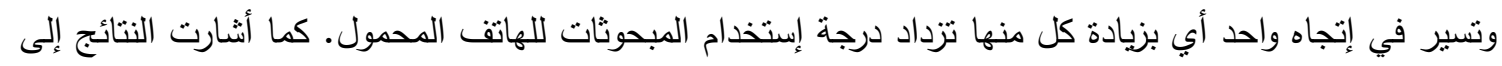
أن المتغيرات المستقلة المدروسة نرتبط مجتمعة بدرجة إستخدام الريفييات للهاتف المحمول في المجالات التنموية

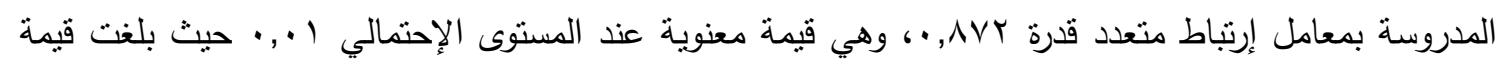

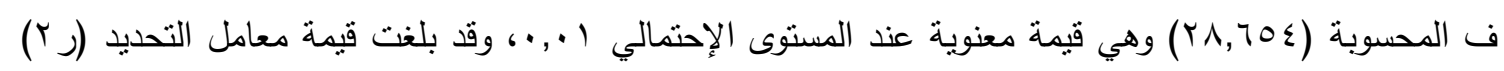

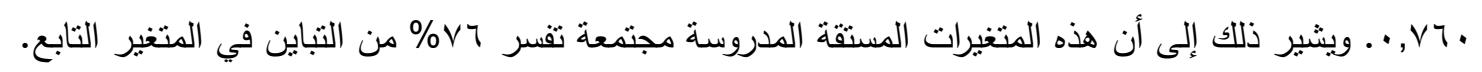
جدول (ع () العلاقات الإرتباطية بين درجة إستخدام المبحوثات للهاتف المحمول ودرجة إستفادتهن منه وكل من

\begin{tabular}{|c|c|c|}
\hline & & المتغيرات المستقله \\
\hline 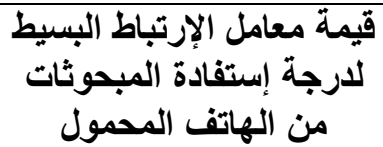 & 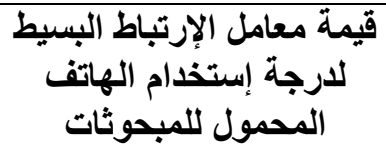 & المتغيرات المستقلة \\
\hline$\cdot, 10 Y_{-}$ & $* *, r \wedge \wedge-$ & 1 - سن المبحوثات. \\
\hline$*{ }^{*} \cdot, r Y \varepsilon$ & $* * \cdot, r \wedge)$ & r- المستوى التعليمي للمبحوثات. \\
\hline$\cdot,|M|$ & $* *$, rOᄉ & "- المستوى التعليمي للزوج. \\
\hline$\cdot, 71-$ & $\cdot$, Y YO- & ع - حجم الأسرة. \\
\hline **., & $\star * \cdot, Y 99$ & 0ـ المشاركة الإجتماعية. \\
\hline ** & $* *, r \leq r$ & 7- مصادر المعلومات. \\
\hline ** $\cdot, r \mu r$ & $\cdot, \varepsilon \cdot r$ & V- التعرض لوسائل الإتصال الجماهيرية. \\
\hline$\cdot, 9 \leq$ & $\cdot, 101$ & 人ـ التجددية. \\
\hline **, rیr & **. & 9 - القيادية. \\
\hline$* * \cdot, r \uparrow \Lambda$ & **,,$r$. & • ــ السلوك الإستتماري. . \\
\hline$\cdot, 9 r$ & $* \cdot, 1 \wedge$ & 1 1 - حيازة الأسرة من الّهو اتف المحمولة. \\
\hline$\cdot, 1 \leq 9$ & **. & r ا - عدد كروت الثحن. \\
\hline$* \cdot, I \vee \wedge$ & $* * ., \leq \leqslant 0$ & سا ـ - مصاريف كروت الثحن. \\
\hline **, rvo & $* *, 0, \varepsilon$ & ـ ا ـ دافعية إستخدام الهاتف المحمول. \\
\hline$* \cdot, 191$ & $* \cdot, 17 r$ & 1 1 - درجة مناسبة الهاتف المحمول. \\
\hline$* *,, Y 07$ & $*^{* *},, \leqslant \vee \uparrow$ & 7 ا ـ المجالات التتموية المفضلة. \\
\hline$\star *,, \varepsilon \cdot \varepsilon$ & $* *, r \wedge I$ & VI ا المصادر المعرفية الهاتفية للمبحوثات. \\
\hline ה* דr, & $* * \cdot, \mu, 0$ & 11 - مصادر الإتصال بالمبحوثة. \\
\hline$\star *,, \vee \vee 1$ & 1 & 9 1 ـ درجة إستخدام الهاتف المحمول. \\
\hline 1 & **, ,,$\vee 71$ & • ץ- درجة الإستفادة من الهاتف المحمول. \\
\hline$\cdot, \wedge \uparrow \xi$ & $\cdot, \wedge \vee Y$ & معامل الإزتباط المتعدد (ر) \\
\hline$\cdot, 790$ & $\bullet, \vee\urcorner$ & معامل التحديد رب \\
\hline$* * Y_{0}, 9 \leq \Lambda$ & $* * Y \wedge, 70 \leqslant$ & قيمة ف \\
\hline
\end{tabular}

وللتعرف على أكثر المتغيرات المستقلة ناثيراً على درجة إستخدام المبحوثات للهاتف المحمول يثير

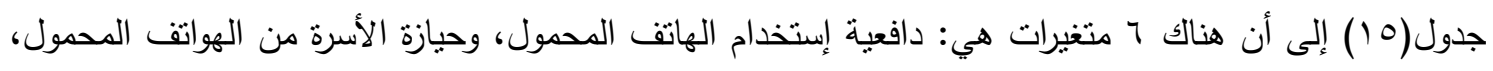
والقيادية، ومصاريف كروت الثحن، والمجالات التتموية الأكثر تفضيلاً، ومستوى تعليم المبحوثة، والسلوك

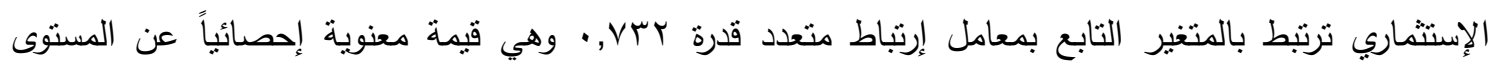




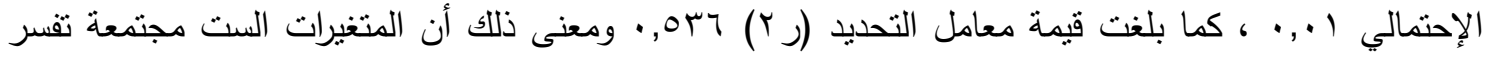
7, به\% من التباين في المتغير التابع. وهذه تنشير لإسهامها في تفسير التباين في المتغير التابع بدرجة كبيرة.

\begin{tabular}{|c|c|c|c|c|}
\hline التباين المفسر & قيمة ت & الجزئي الإقياسي & معامل الإنحدار & المتغيرات المستقلة \\
\hline$\cdot, Y \circ \leqslant$ & $* * r, Y, r$ & $\cdot, 114$ & $r, 1 Y T$ & 1 ـ دافعية إستخدام الهاتف المحمول \\
\hline$\cdot, \leqslant .0$ & $* * \tau, Y \vee$. & 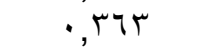 & Y,TY & r- حيازة الأسرة من الهو اتف المحمولة \\
\hline$\cdot, \leqslant \vee \vee$ & $\star * \varepsilon, \varepsilon, \varepsilon$ & $\cdot$, rVq & • & r- مصاريف كروت الثحن \\
\hline$\cdot, 0.7$ & $* * r, V \leqslant$. & $\cdot, \wedge \varepsilon$ & r, ror & ع ـ المجالات التنموية المفضلة لديها \\
\hline$\cdot, 0,1$ & $\star \star *, r, \cdot$ & $\cdot, 174$ & $r, \cdot, v$ & 0ـ مستوى تعليم المبحوثة \\
\hline$\cdot, 044$ & $* * \quad, 19$. & $\cdot, 1 Y 7$ & $r, \mu, \varepsilon$ & 7ـ السلوك الإستثماري \\
\hline
\end{tabular}

ب- العلاقات الإرتباطية والتأثيرية بين المتفيرات المستقلة المدروسة ودرجة إستفادة المبحوثات من إستخدام

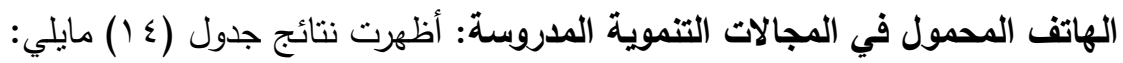
وجود علاقة إرتباطية طردية معنوية عند المستوى الإحتمالي ا.,. بين درجة إستفادة المبحوثات من إستخدام الهاتف المحمول في المجالات التتموية المدروسة وكل من: المستوى التعليمي للمبحوثة، والمشاركة الإجتماعية، وتعدد مصادر المعلومات، والتعرض لوسائل الإتصال الجماهيرية، والقيادية، والسلوك الإستثماري، ودواعي إستخدام الهاتق المحمول، والمجالات التتموية المفضله، والمصادر المعرفيه الهاتفية، ومصادر الإتصال بالمبحوثات، ودرجة إستخدام الهاتف المحمول. كذلك وجود علاقة إرتباطية معنوية طردية عند المستوى الإحتمالي 0., • وبين المتغير التابع المذكور ودرجة مناسبة الهاتف المحمول، ومصاريف كروت الثحن. في حين لم تثبت معنوية العلاقة بين هذا المتغير التابع والمتغيرات المستقلة الأخرى المدروسة، وبناء على هذه النتائج فإنه يمكن قبول الفرض البحثي الثاني جزئياً بالنسبة لباقى المتغيرات المستقلة المدروسة التي ثبت أن لها علاقة معنوية بالمتغير التابع المذكور ورفضه بالنسبة لباقى المتغيرات المستقلة المدروسة الأخرى التي لم يثبت ان لها علاقة إرتباطية معنوية بالمتغير التابع. ويمكن تفسير هذه العلاقة الإرتباطية الطردية بين كل من المتغيرات المستقلة المدروسة والمتغير التابع المذكور بأن كل من هذه المتغيرات المستقلة تكون متلازمة وتسير في إتجاه واحد مع لإنع

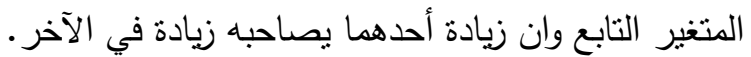
كما أثنارت النتائج إلى أن المتغيرات المستقلة المدروسة ترتبط مجتمعة بدرجة إستفادة المبحوثات من الهاتف المحمول في المجالات التتموية المدروسة بمعامل الإرتباط متعدد قدره عبر,، وهي قيمة معنوية عند

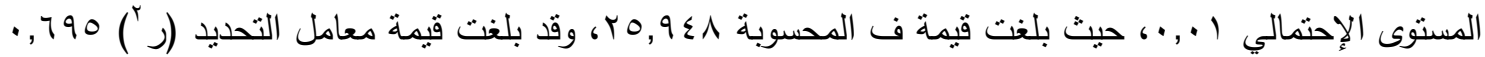
وتشير تلك النتائج أن هذه المتغيرات المستقلة المدروسة مجتمعة تفسر 79,0\% من التباين في المتغير التابع. وللوقوف على أكثر المتغيرات المستقلة تأثنيراً على درجة إستقادة المبحوثات من الهاتف المحمول في المجالات التموية المدروسة كتغير تابع، فقد أوضحت نتائج جدول (7 (1) وجود خمس متغيرات مستقلة في المجالات التتموية المفضلة، والقيادية، ودواعي إستخدام المبحوثات للهاتف المحمول، والمشاركة الإجنماعية،

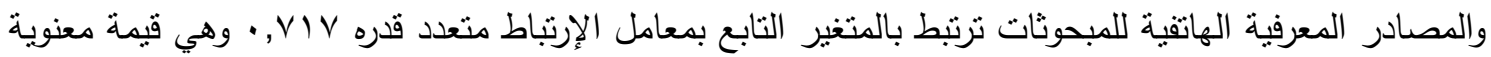

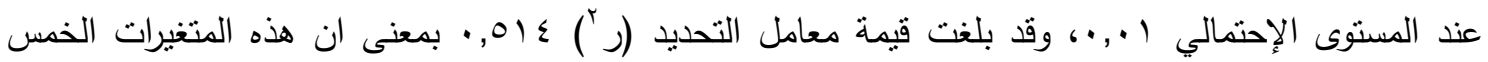


المستقلة مجتمعة تفسر ع , 10\% من التباين في المتغير التابع. وهذه النسبة تشير إلى قوة إسهام هذه المتغيرات الخمس في تفسير التباين في هذا المتغير التابع.

جدول (1 1) العلاقة التأثيرية بين المتغيرات المستقلة وبين درجة إستفادة المبحوثات من إستخدام الهاتف المحمول

\begin{tabular}{|c|c|c|c|c|}
\hline التباين & $\begin{array}{l}\text { ق قيمة } \\
\text { (ت) }\end{array}$ & الجزئي اللقياسي & معامل الإنحدار & المتغيرات المستقلة \\
\hline$\cdot, \varepsilon 1 \wedge$ & ** 0, rYT & $\cdot, \Gamma \vee \wedge$ & $r, \varepsilon r \leq$ & 1 - المجالات التتموية المفضلة لديها \\
\hline . sor & $* * r, q \wedge r$ & $\cdot, Y \wedge$ & 1,111 & 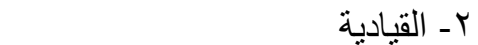 \\
\hline$\cdot, \varepsilon \wedge \varepsilon$ & $* * r, \varepsilon) V$ & $\cdot$, YO. & $r, r r$ & ז- دافعية إستخدام الهاتف المحمول \\
\hline$\cdot, 0 . r$ & $* * Y, 07$. & $\cdot, 1 \wedge \wedge$ & $\cdot, 90 \mathrm{~V}$ & ـ - المشاركة الإجتماعية \\
\hline$\cdot, 01 \leqslant$ & $* * Y, Y \leq 0$ & $\cdot, 1 \leq 0$ & 0,719 & هـ المصادر المعرفية الهاتفية \\
\hline
\end{tabular}

سادساً: مقترحات المبحوثات لزيادة إستفادتهن من إستخدام الهاتف المحمول من وجهة نظرهن:

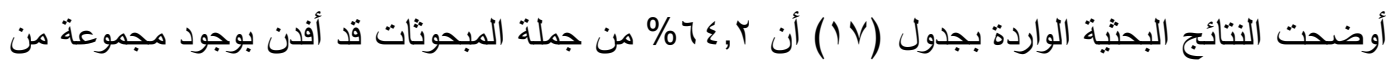
المقترحات التي يمكن أن تزيد من فاعلية إستخدامهن وإستفاداتهن من الهاتف المحمول كوسيلة إتصالية في زيادة معلوماتهن ومعارفهن في الدجالات التتموية، وكانت كالآتي: 1- المقترحات المادية منها: تخفيض أسعار المكالمات والباقات والكروت، وتوفير الكروت في الكاتهات المناطق البعيدة عن المدن، وتخفيض أسعار الثحن، وتخفيض أسعار أجهزة الهاتف المحمول، وتخفيض أسعار إثتراكات الإنترنت، وتوفير خطوط متخصصة بأسعار مخفضه، توفير أعمال صيانة للهاتف المحمول بأسعار معقولة. r- المقترحات الخاصة بالإنترنت وهي: نوفير خدمة الإنترنت، وزيادة سرعته، وتحسين شبكته.

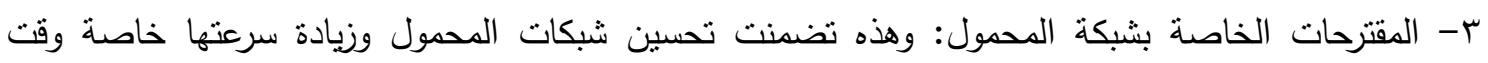
الذروة، وتغطية الثبكة للمناطق البعيدة عن المدن، وتقوية الثبكات، عمل شبكة تربط بين الريفيين خاصة بمديريات الزراعة والمراكز الإرشادية، ومحطات البحث والرائدات الريفيات والمناطق الريفية عامة. ع - المقترحات الخاصة بالريفيات فهي تشمل: نوعية الريفيات بترشيد إستخدام الهاتف المحمول، والإقتصاد في رلي

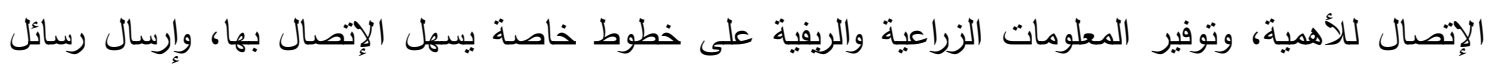

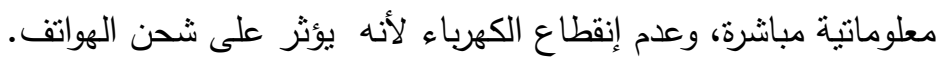

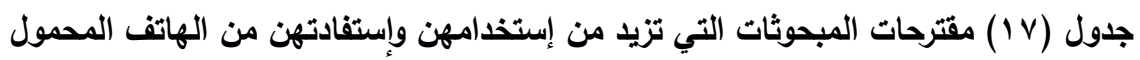

\begin{tabular}{|c|c|c|}
\hline$\%$ & 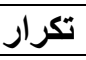 & المقترحات \\
\hline $0 \leqslant, \wedge$ & ov & 1- مقترحات مادية \\
\hline$\leqslant 0, r$ & $\leqslant V$ & r- مقترحات خاصة بالأنترنت \\
\hline$\Gamma \cdot$, & Tr & r- مقترحات خاصة بشبكات المحمول \\
\hline rA, $\varepsilon$ & r. & ـ - مقترحات خاصة بالريفيات \\
\hline
\end{tabular}

التوصيات

في ضوء النتائج البحثية التي أسفرت عنها الدراسة في منطقة البحث فإنه يمكن زيادة فاعلية إستخدام وإستفادة المبحوثات من الهاتف المحمول بمنطقة الدراسة وما قد يتثابه معها في مناطق آخرى وذلك من خلال التوصيات المقترحة التالية: 
1- في ضوء إنتشار الهاتف المحمول بين الريفيات المبحوثات يوصي البحث بضرورة نوعية الريفيات بترشيد إستخدامه والإستفادة منه كطريقة إنصالية فردية سهلة ورخيصة التكاليف خاصة في المجالات التتموية.

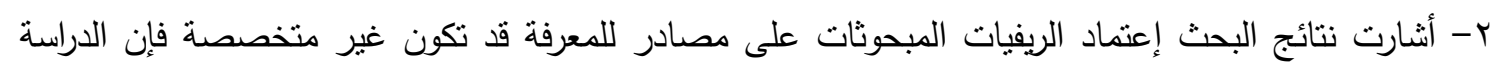

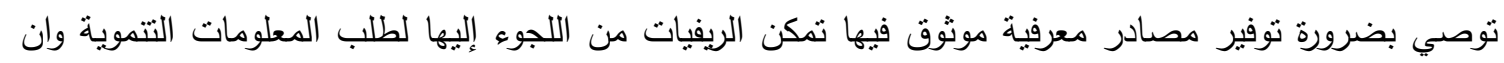

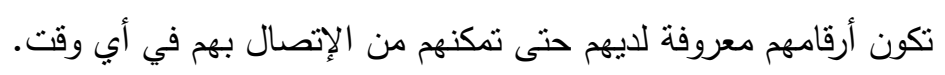

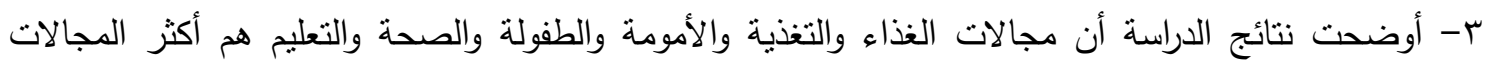

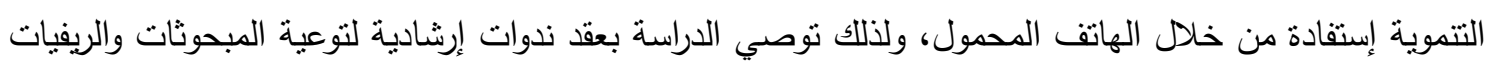
عامة بكيفية إستخدام الهاتف المحمول بطريقة إقتصادية وفعالة والإستفادة منه. ع- في ضوء فثل المبادرة التي قامت بها وزارة الزراعة (مركز البحوث الزراعية ) وشركة فودافون في 10 يونيو

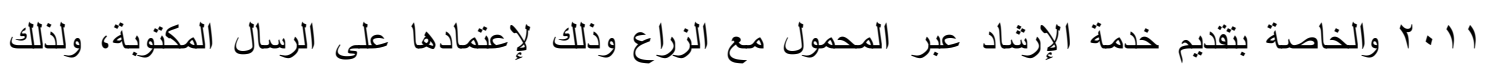

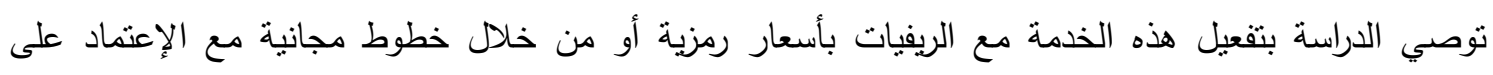
الرسائل الصوتية او المحادثة المباشرة مع الريفيات للنغلب على أمية نسبة كبيرة من الريفيات.

المراجع

أبو حليمة، وفاء ومحمد إبراهيم عنتر. 999 19. دراسة بعض الجوان المتعلقة بممارسات الريفيات للصناعات الريفية الصغيرة بالوجهين البحري والقبلي. نشرة بحنية رقم ربr. معهد بحوث الإشئد الزراعي والتتمية

\section{الريفية.}

الإمام، مي محمد.م . .r. دراسة إجتماعية لدور المرأة الريفية في بعض مجالات التتمية الريفية. رسالة ماجستير. كلية الزراعة.جامعة المنصورة.

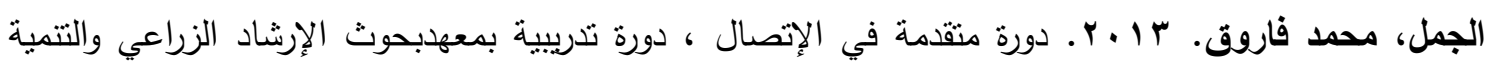
الريفية- القاهرة.

الخولي، حسين ذكي ومحمد فتحي الشاذلي وشادية حسن فتحي ـ ـ 9 اــ الإرشاد الزراعي. كلية الزراعة. جامعة الإسكندرية.

السيد. عزيزة عوض الله. r..... مجالات العمل الإرشادي مع المرأة الريفية في المؤتمر الساد للإرشاد الزراعي وتتمية المرأة الريفية. المركز المصري الدولي للزراعة. الدقي. القاهرة.

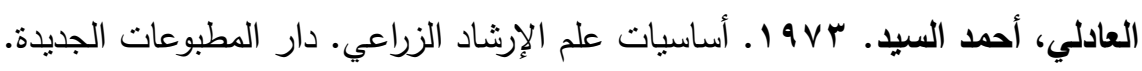

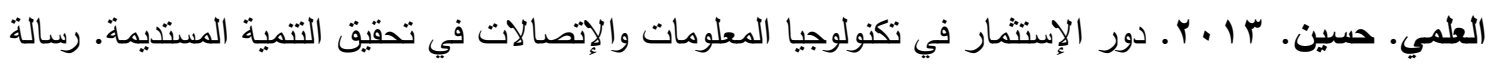

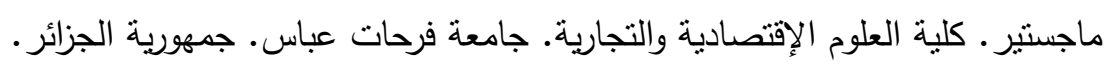
الطنويي، محمد عمر. 991 19 ـ مرجع الإرشاد الزراعي. دار النهضة العربية للطباعة والنشر • بيروت. الطنويب، محمد عمر . 1 . . r أ. المراة الريفية. مكتبة ومطبعة الإشعاع الفنية. الإسكندرية. الطنويي، محمد عمر . 1 . . ب ب. نظريات الإتصال. مكتبة ومطبعة الإشعاع الفنية. الإسكندرية.

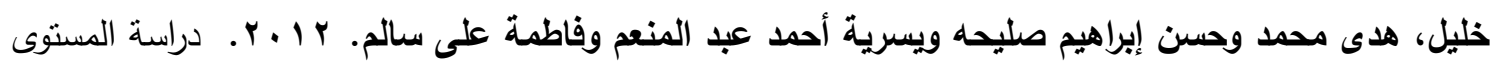
المعرفي لدى المرأة الريفية في بعض مجالات الإقتصاد المنزلي. مجلة الزقازيق للبحوث الزراعية. وجـ (1). 
خطاب، مجدي عبد الوهاب. ه.. . . الإتصال الفعال في العمل الإششادي الزراعي. قسم الإرشاد الزراعي. كلية

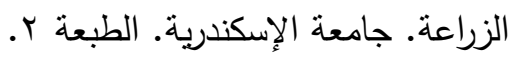

دي كوستا، فاليري. Y l • Y. المبادئ التوجيهية لسياسات اليونيسكو فيما يتعلق بالتعلم بلأجهزة المحمولة. منظمة الأمم المتحدة للتربية والعلم والنقافة.

سالم، مروة السيد عبد الرحيم.ب ا •r+. دورة متقدمة في الإتصال دورة تدريبية بمعهد بحوث الإرشاد الزراعي والتتمية الريفية. فرع الإسكندرية .

سليم،نجم الدين عبدالله وطارق محمد صالح الحرياوي.ب l ـ. . مجالات إستخدام الهاتف النقال في العمل الإرشادي الزراعي بمحافظة نينوي من وجهة نظر العاملين. مجلة جامعة تكريت للعلوم الزراعية.العراق

$\cdot(r)$ (r)

صالح، صبري مصطقى. 9 V 19 الإرشاد الزراعي. طرقه ومعيناته التعليمية. جامعة عمر المختار . ليبيا.

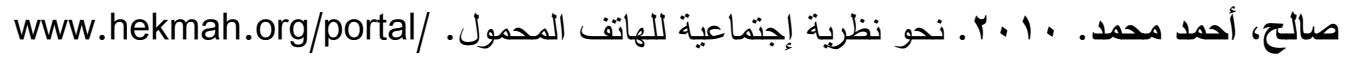

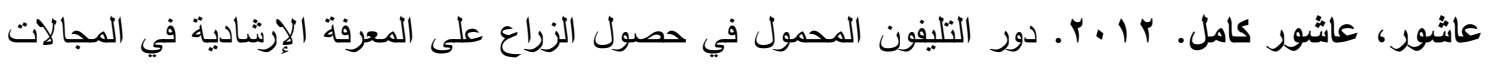

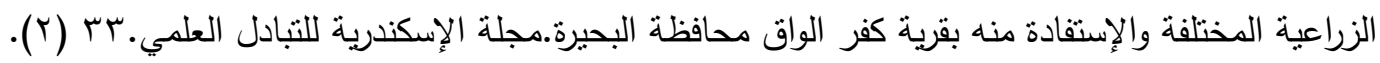

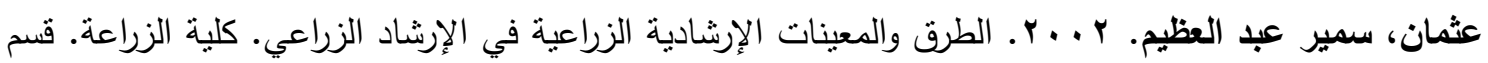

$$
\text { الإرشاد الزراعي. جامعة الإسكندرية. }
$$

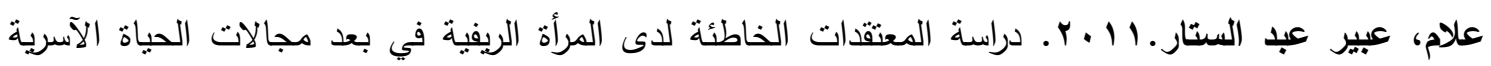

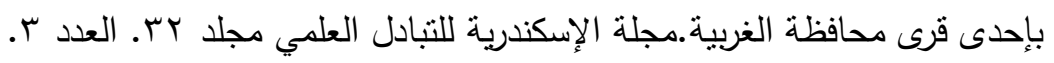

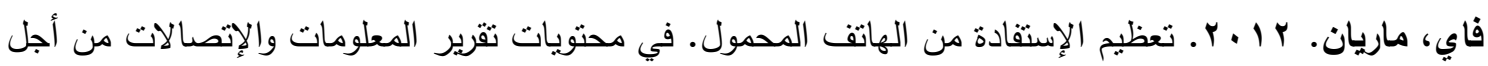
التتمية. البنك الدولي. قاسم، محمد حسن.9 . . ب طرق الإتصال الحديثة في خدمة قضايا التتمية. ندورة عن " دور الإرشاد الزراعي ف

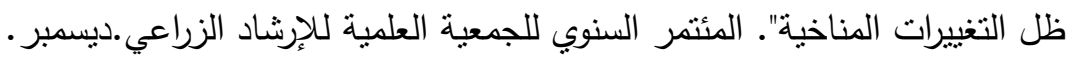

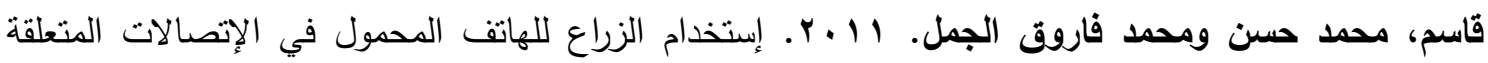
بالزراعة. الجمعية العلمية للإرشاد الزراعي، المجلد (10 (1). العدد الأول.

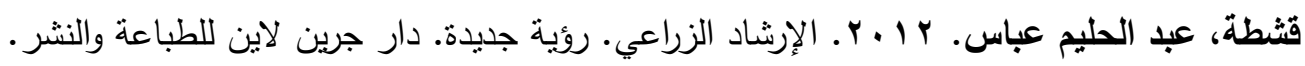

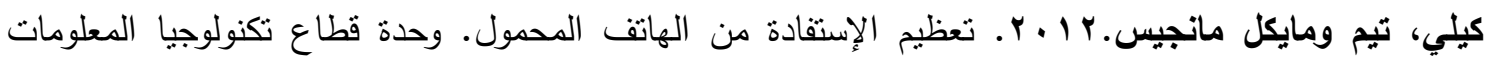

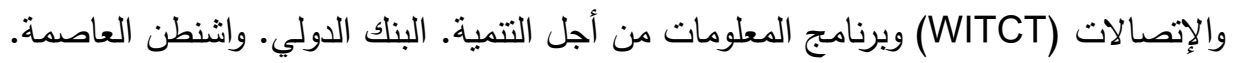

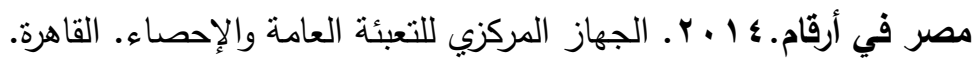
مدكور، طه منصور ونهى الزاهي السعيد حس..؛ 1 .Y.تحليل مضمون مجلة الإششاد الزراعي للموضوعاء

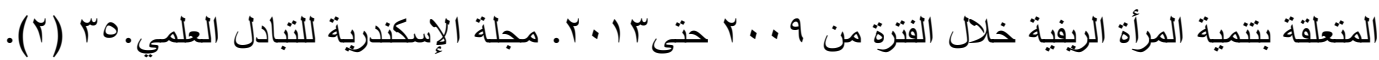
مكاوي، حسن عماد وليلى حسين السيد.^ . . ؟ ـ الإتصال ونظرياته المعاصرة. الدارالمصرية اللبنانية. الطبعة 7. مكاوي، حسن عماد.9 . . . . نظريات الإعلام. الدار العربية للنشر والتوزيع. الطبعة الأولى.

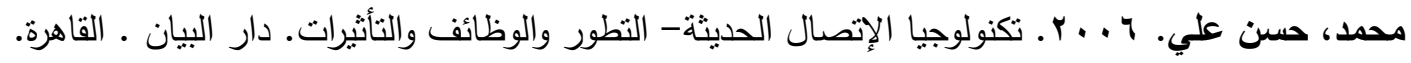
www.gover/ar.com وزارة الإتصالات المصرية 


$$
\begin{aligned}
& \text { وهبه، أحمد جمال الدين وأماني عبد المنعم السيد وهيام محمد عبد المنعم حسيب. ج . . r. علاقة طموح الفتيات } \\
& \text { الريفيات ببعض العوامل الإجتماعية في بعض المناطق الريفية بمحافظتي البحيرة والمنيا. مجلة إسكندرية } \\
& \text { للبحوث الزراعية. • (1). }
\end{aligned}
$$

Abraham, R. (2007). "Mobile Phones and Economic Development: Evidence from the Fishing Industry in India", Information Technology and International Development, MIT press, Volume 4, Number 1.

Bolarinwa, K. K., and R. A. Oyejinka (2011). " Use of Cell Phone by Farmers and its Implication on Farmers Production Capacity in Oyo State Nigeria". World Academy of Science, Engineering and Technology 75. http//www.wast.org/journals/wes/ v75/v75-118.pdf.

FAO 1998. wwww.FAO.org/docrep/x2520A/x2550904.htm

Fong, M. W. L. (2009). "Digital Divide between Urban and Rural Regions in China", the Electronic Journal on Information System in Developing Countries, EJISDC, vol.36, No.6, Pp 1-12: http//www.ejisdc.org/ojs2/index.php/ ejisdc/article/view file $/ 532 / 268$.

Fernanda, M. (2011). "Evry Body has a mobile phone" http//www.e-agriculture.Org /blog/everybody-has-mobile-phone\&usg.

Gamble, T. and G. M. Chael(2010). " Communication Works" New York. Institution of technology, Mc, braw, HH. Gifts.

GSMA (2014). http://www.gsma.com/mobilefordevelopment/wp-content/uploads /2014/06/Women_in_Agriculture a_Toolkit_for_Mobile_Services_Practitioners.pdf

IFAD 2005. www. Ifad.org

KansasUniverstyhttps://kuscholarworks.ku.edu/bitstream/handle/1808/14544/Bonthu ku_0099M_13245_DATA_1.pdf;jsessionid=D961F6207616380E5AAE50F61D9 C0ㄹ? sequence $=1$

Mauritius Agriculture Ne ws (2011). http//www.news-agriculture.blogspot.com/02/ use-of-ict-in-agriculture.html.

Oungs, 2002. http//www.hekmah.org/portal/

Richardson, D. (2003). Agricultural extension transforming ICTS? Championing Univerty access, ICT Observatory: ICTS- Transforming agricultural extension, Wageningen, 23-25 septemper 2013. http//www.cta int/observatory 2013/ppt presentation/Richardson overview.pdf.

Saravanan, R. (2011). http://www.aesa-gfras.net/Resources/file/mAgri_Extension_ Saravanan \%20Raj.pdf

Sief, A. S., Elizabeth Kiondo, Joyce G. Lyiom-Macha.(2010). "Contribution of Mobile Phones to Rural Livelihoods and Poverty Reduction in Morogoro Region, Tanzania" Ejisdc,42,3,115.http//www.ejisdc.org/ojs2/index.php/ejisdc/article/view file/660/323.

Smart Phone. http://www.e-agriculture.org/content/exploring-suitable-interfacesagriculture-based-smartphone-apps-india

We farm. http://wefarm.info/ 


\title{
Determinants of Benefits of Rural Women from Using Mobile Phones in Development all Fields in some Villages of El- Beheira Governorate
}

\author{
Safaa Ahmed Fahim El-Bindary El-Deeb \\ Agricultural Extension and Rural Development Research Institute, ARC, \\ Egypt
}

\begin{abstract}
This study aims at recognizing the determinants of benefits of rural women from using mobile phones in developmental fields in some villages of ElBeheira governorate by; Identifying some characteristics of respondents, determining the respondents' use of a mobile phoneto access information and knowledge on developmental studies, determining the degree of benefit the respondents from using a mobile phone in the studied fields of development, and studying the regression relations between some independent variables and each of; the degree of use of a mobile phone in the fields of development, the degree of benefit from a mobile phone use in the fields of development as two dependent variables, and identifying the respondents suggestions to overcome the obstacles that limit their use of moble phone and getting benefit from it in the field of development.
\end{abstract}

A questionnaire through personal interview was used to collect data from 162 rural women who possess mobile phones.

Variety of methods were applied for data interpretation and presentation including: percentage, duplicates, arithmetic mean, standard deviation, coefficient of simple correlation, stepwise multiple regression analysis, $\mathrm{T}$ test and $\mathrm{F}$ test.

Major findings of the study can be summarized as follows:

1- The following developmental areas are arranged in descending order according to the degree of benefit of respondents using a mobile phone: food and nutrition, maternal and childhealth, education, culture, marketing, rationalizing consumption, agricultural production, poultry, environment, animal production, and small businesses.

2- $31.5 \%$ of respondents have low degree of use of mobile phone in fields of development, $50 \%$ medium, and $18.5 \%$ have high degree.

3- $30.8 \%$ of respondents have low degree of benefit from using a mobile phone, while the $48.8 \%$ have intermediate benefit, and $20.4 \%$ high.

4- There are six variables that together explain $53.6 \%$ of the variation in the degree of use of the respondents of a mobile phone, which are: motivation to use a mobile phone, possession of the family of mobile phones, expenses of scratch cards, number of preferred fields of development, the respondents' level of education, and the investment behavior.And five variables together explain $51.4 \%$ of the variation in the degree of benefit of respondents using a mobile phone: number of preferred fields of development, leadership, motivation to use a mobile phone, social participation, and sources of knowledge from a mobile phone.

5- There are several proposals for the respondent to increase the effectiveness of their use and benefit from a mobile phone while include is: material proposals, Internet related proposals, mobile network related proposals, and respondents related proposals. 
